\title{
Oxidation Enhances Aerosol Nucleation: Measurement of Kinetic Pickup Probability of Organic Molecules on Hydrated Acid Clusters
}

\author{
Jozef Lengyel, ${ }^{*, \dagger}$ Andriy Pysanenko, ${ }^{\ddagger}$ Karolína Fárníková, ${ }^{\ddagger}$ Eva Pluhařová, ${ }^{*, \ddagger}$ and Michal \\ Fárník*,‡ \\ † Chair of Physical Chemistry, Department of Chemistry, Technical University of Munich; \\ Lichtenbergstraße 4, 85748 Garching, Germany. E-mail: jozef.lengyel@tum.de \\ $\ddagger$ J. Heyrovský Institute of Physical Chemistry, v.v.i., Czech Academy of Sciences; Dolejškova 2155/3, \\ 18223 Prague, Czech Republic. E-mails: michal.farnik@jh-inst.cas.cz, eva.pluharova@jh-inst.cas.cz
}

\section{EXPERIMENTAL DETAILS}

The pickup experiment was described in detail elsewhere. ${ }^{1}$ We generated the molecular beam of $\left(\mathrm{HNO}_{3}\right)_{M}\left(\mathrm{H}_{2} \mathrm{O}\right)_{N}$ clusters in supersonic expansion. ${ }^{2-4} A$ stainless steel reservoir containing nitric acid solution (65\% Lach-Ner) was resistively heated to $T_{R}=338 \mathrm{~K}$ in a source vacuum chamber, and the vapor was carried by buffer gas $\mathrm{He}$ at $P_{0}=2$ bars to a nozzle connected directly to a reservoir and heated to $T_{0}=348 \mathrm{~K}$. The gas expanded through a conical nozzle into a vacuum of $\sim 10^{-4} \mathrm{mbar}$. The nozzle had $90 \mu \mathrm{m}$ diameter and $30^{\circ}$ opening angle and was $2 \mathrm{~mm}$ long. About $2 \mathrm{~cm}$ from the nozzle, the clusters passed through a skimmer $(\varnothing 0.8 \mathrm{~mm})$ and entered a $17 \mathrm{~cm}$ long chamber which could be filled with a gas at a well-controlled pressure $p_{p}$ for the pickup.

The clusters picked up the organic molecules and carried them through two differentially pumped vacuum chambers further downstream approximately $150 \mathrm{~cm}$ from the skimmer to a time-of-flight mass spectrometer. Here the clusters were ionized by $70 \mathrm{eV}$ electrons from an electron gun with a frequency of $5 \mathrm{kHz}$. The ionization pulse of $2 \mu \mathrm{s}$ was followed by $0.5 \mu$ s delay time before the ions were extracted by $3 \mathrm{kV}$ pulse into the time-offlight region, and subsequently they were accelerated to $6 \mathrm{keV}$. After a $95 \mathrm{~cm}$ flight path, the ions were detected with a multichannel plate and the mass spectra were recorded.

To prove sticking collisions of the clusters with molecules, we have measured the cluster velocities as reported previously. ${ }^{5-8}$ For this purpose, a quadrupole mass spectrometer (QMS) with $70 \mathrm{eV}$ continuous electron ionization was used as a detector at the end of the apparatus. The QMS was set to a particular fragment ion mass. The molecular beam was interrupted with a pseudorandom chopper, and the recorded time-dependent signal represented a convolution of the cluster flight-time distribution with the pseudorandom chopper 
sequence. The flight-time distribution was obtained by the signal deconvolution and from the known flight path of $L=151 \mathrm{~cm}$, the velocity distribution was evaluated.

\section{CALCULATIONS}

The binding of VOCs to acidic water clusters was characterized by ab initio calculations. We investigated the following clusters $\mathrm{HNO}_{3}\left(\mathrm{H}_{2} \mathrm{O}\right)_{6}$ and $\mathrm{X} \cdot \mathrm{HNO}_{3}\left(\mathrm{H}_{2} \mathrm{O}\right)_{6}$, where $\mathrm{X}$ stands for $\mathrm{CH}_{3} \mathrm{OH}$, 2-methyl-3-buten-2-ol, 3-methyl-3-buten-1-ol, isoprene, pinene and verbenone. In order to find the most stable structures of the clusters, their configurational space was sampled by Born-Oppenheimer molecular dynamics. Ab initio molecular dynamics was chosen in order to allow for potential proton transfer. The electronic structure of the system was treated by the revPBE functional ${ }^{9}$ with the D3 dispersion correction. ${ }^{10}$ The core electrons were described by the Goedecker-Tetter-Hutter norm-conserving pseudopotentials, ${ }^{11}$ and Kohn-Sham orbitals were expanded in TZV2P MOLOPT and basis set. ${ }^{12}$ A cutoff of 400 Ry was used for the auxiliary plane-wave basis set. The equations of motion were integrated with a time step of 0.5 fs The temperature was maintained by the CSVR thermostat with a coupling constant of 50 fs. ${ }^{13}$ For each system, we at first collected at least one 15 ps trajectory at $300 \mathrm{~K}$ which was followed by a $20 \mathrm{ps}$ trajectory at $200 \mathrm{~K}$. The starting structure for the simulation at $200 \mathrm{~K}$ was either the last configuration from the simulation at $300 \mathrm{~K}$ or a topologically different isomer from the last 5 ps. The number of independent trajectories for each system was as follows: $\mathrm{HNO}_{3}\left(\mathrm{H}_{2} \mathrm{O}\right)_{6}(1$ at $300 \mathrm{~K}, 2$ at $200 \mathrm{~K}), \mathrm{CH}_{3} \mathrm{OH} \cdot \mathrm{HNO}_{3}\left(\mathrm{H}_{2} \mathrm{O}\right)_{6}(2$ at $300 \mathrm{~K}, 2$ at $200 \mathrm{~K}$ ), 2-methyl3-buten-2-ol. $\mathrm{HNO}_{3}\left(\mathrm{H}_{2} \mathrm{O}\right)_{6}\left(1\right.$ at $300 \mathrm{~K}, 2$ at $200 \mathrm{~K}$ ), 3-methyl-3-buten-1-ol. $\mathrm{HNO}_{3}\left(\mathrm{H}_{2} \mathrm{O}\right)_{6}(1$ at 300 $\mathrm{K}, 2$ at $200 \mathrm{~K})$, isoprene $\cdot \mathrm{HNO}_{3}\left(\mathrm{H}_{2} \mathrm{O}\right)_{6}(2$ at $300 \mathrm{~K}, 3$ at $200 \mathrm{~K})$, pinene. $\mathrm{HNO}_{3}\left(\mathrm{H}_{2} \mathrm{O}\right)_{6}(2$ at 300 $\mathrm{K}, 2$ at $200 \mathrm{~K})$, verbenone $\cdot \mathrm{HNO}_{3}\left(\mathrm{H}_{2} \mathrm{O}\right)_{6}(2$ at $300 \mathrm{~K}, 2$ at $200 \mathrm{~K})$.

Snapshots from the $200 \mathrm{~K}$ trajectories were spaced by $1 \mathrm{ps}$, and each structure was then optimized at the M06-2X/aug-cc-pVDZ level of theory. ${ }^{14}$ Frequency analysis was performed to confirm the local minimum. The lowest energy structure for each system was used to evaluate the biding energy of molecule $\mathrm{X}$ to the $\mathrm{HNO}_{3}\left(\mathrm{H}_{2} \mathrm{O}\right)_{6}$ cluster at M06-2X/augcc-pVDZ, MP2/aug-cc-pVTZ, and for computationally feasible cases at the CCSD(T)/aug-ccpVDZ level. The binding energy includes zero-point vibrational energy obtained employing M06-2X/aug-cc-pVDZ and the counter-poise correction ${ }^{15-16}$ for the basis set superposition error. All quantum chemical calculations were performed in the Gaussian $09^{17}$ and the molecular dynamics simulations in the CP2K program package. ${ }^{18-19}$ 


\section{EXPERIMENTAL RESULTS}

\section{III. a) Mass spectra and fragment series}

Figure S1 shows the measured mass spectra. As outlined above, in our experiment mixed $\left(\mathrm{HNO}_{3}\right)_{M}\left(\mathrm{H}_{2} \mathrm{O}\right)_{N}$ clusters pass through the pickup cell filled with a very diluted gas of molecules $X$. As the cluster collides with $X$, the molecule can be adsorbed on the cluster, and the generated $\mathrm{X} \cdot\left(\mathrm{HNO}_{3}\right)_{M}\left(\mathrm{H}_{2} \mathrm{O}\right)_{N}$ cluster continues through ultrahigh vacuum without further collisions towards the detector, where the clusters are ionized and mass spectra recorded. Upon the ionization, the molecules fragment and the cluster constituents can evaporate resulting in protonated ion fragment series $\left(\mathrm{HNO}_{3}\right)_{m}\left(\mathrm{H}_{2} \mathrm{O}\right)_{n} \mathrm{H}^{+}$and $\mathrm{X} \cdot\left(\mathrm{HNO}_{3}\right)_{m}\left(\mathrm{H}_{2} \mathrm{O}\right)_{n} \mathrm{H}^{+}$ observed in the mass spectra.

Figure $\mathrm{S} 1$ (a) shows the measured mass spectrum of the pure mixed $\left(\mathrm{HNO}_{3}\right)_{M}\left(\mathrm{H}_{2} \mathrm{O}\right)_{N}$ clusters and panels (b) to (d) show the mass spectra after the pickup of methanol, 3-methyl-3buten-1-ol and 2-methyl-3-buten-2-ol molecules, respectively. All the spectra contain the same $\left(\mathrm{HNO}_{3}\right)_{m}\left(\mathrm{H}_{2} \mathrm{O}\right)_{n} \mathrm{H}^{+}$ion series, which were interpreted for the pure $\left(\mathrm{HNO}_{3}\right)_{M}\left(\mathrm{H}_{2} \mathrm{O}\right)_{N}$ clusters elsewhere..$^{2-4}$ In addition, new series appear in the spectra after the pickup, and the mass peaks corresponding to the individual series are connected by the dashed lines in panels (b) to (d). These series have similar character to the $\left(\mathrm{HNO}_{3}\right)_{m}\left(\mathrm{H}_{2} \mathrm{O}\right)_{n} \mathrm{H}^{+}$ion series, but the new mass peaks are shifted by the mass of the corresponding molecules, i.e. by $\mathrm{m} / \mathrm{z}=32$ for methanol and 86 for 3-methyl-3-buten-1-ol and 2-methyl-3-buten-2-ol. These series can be assigned to $\mathrm{X} \cdot\left(\mathrm{HNO}_{3}\right)_{m}\left(\mathrm{H}_{2} \mathrm{O}\right)_{n} \mathrm{H}^{+}$ions, $X$ stands for $\mathrm{CH}_{3} \mathrm{OH}, \mathrm{CH}_{2}=\mathrm{C}\left(\mathrm{CH}_{3}\right) \mathrm{CH}_{2} \mathrm{CH}_{2} \mathrm{OH}$, $\mathrm{CH}_{2}=\mathrm{CHC}\left(\mathrm{CH}_{3}\right)_{2} \mathrm{OH}$.

In the right column of Figure $\mathrm{S} 1$ the pure mixed $\left(\mathrm{HNO}_{3}\right)_{M}\left(\mathrm{H}_{2} \mathrm{O}\right)_{N}$ cluster mass spectrum is shown again in a logarithmic scale (e) together with the spectra for the pickup of verbenone (f), isoprene ( $\mathrm{g}$ ), and $\alpha$-pinene $(\mathrm{h})$. The reason for the logarithmic scale is the small intensity of the additional mass peaks in the spectra corresponding to the pickup of these molecules. The peaks are orders of magnitude weaker than the pickup series in the left panels, yet they are unambiguous. For verbenone (f), they are again quite similar to the pure $\left(\mathrm{HNO}_{3}\right)_{m}\left(\mathrm{H}_{2} \mathrm{O}\right)_{n} \mathrm{H}^{+}$ion series and could be again assigned to $X \cdot\left(\mathrm{HNO}_{3}\right)_{m}\left(\mathrm{H}_{2} \mathrm{O}\right)_{n} \mathrm{H}^{+}$ions with $\mathrm{X}=\mathrm{C}_{10} \mathrm{H}_{14} \mathrm{O}$. For isoprene (g), only the $\mathrm{X} \cdot\left(\mathrm{HNO}_{3}\right)_{m}\left(\mathrm{H}_{2} \mathrm{O}\right)_{n} \mathrm{H}^{+}, \mathrm{X}=\mathrm{CH}_{2}=\mathrm{C}\left(\mathrm{CH}_{3}\right)-\mathrm{CH}=\mathrm{CH}_{2}$, series with $m=0$ is indicated by the dashed red line in panel $(\mathrm{g})$, however, very weak peaks corresponding to $m>0$ could be still identified, as outlined in Figure S2. For $\alpha$-pinene (h), all series corresponding to $\mathrm{X} \cdot\left(\mathrm{HNO}_{3}\right)_{m}\left(\mathrm{H}_{2} \mathrm{O}\right)_{n} \mathrm{H}^{+}, \mathrm{X}=\mathrm{C}_{10} \mathrm{H}_{16}$, are within the noise limit. 

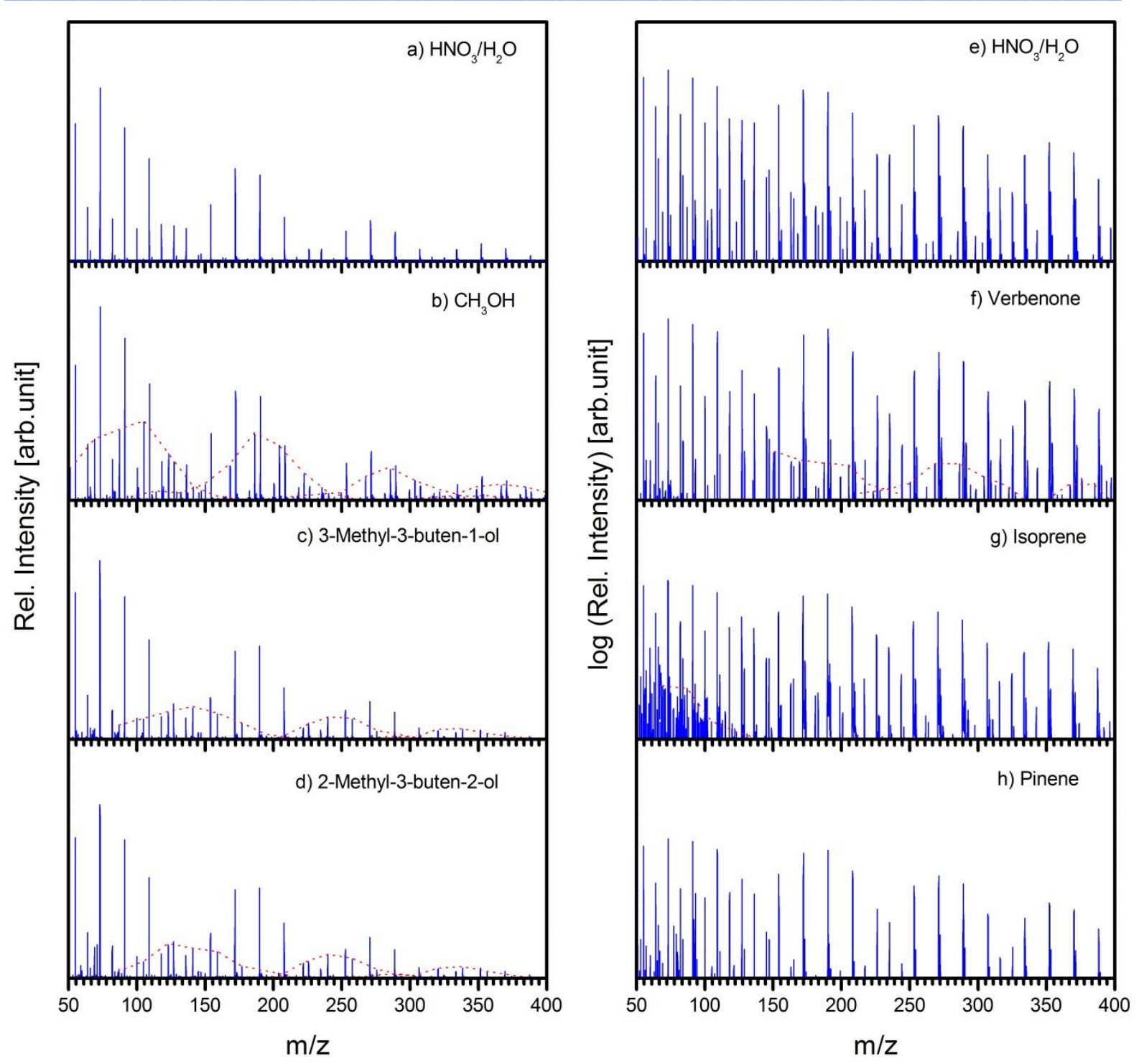

Figure S1: Measured mass spectra of the pure $\left(\mathrm{HNO}_{3}\right)_{M}\left(\mathrm{H}_{2} \mathrm{O}\right)_{N}$ clusters (a) and (e). The mass spectra after the pickup of methanol (b), 3-methyl-3-buten-1-ol (c), 2-methyl-3-buten-2-ol (d), verbenone (f), isoprene $(\mathrm{g})$, and pinene $(\mathrm{h})$. Additional series $\mathrm{X} \cdot\left(\mathrm{HNO}_{3}\right)_{m}\left(\mathrm{H}_{2} \mathrm{O}\right)_{n} \mathrm{H}^{+}$in the pickup spectra are labeled (red dotted line). The spectra (e)-(h) are plotted in log-scale due to the small intensity of the pickup series.

To demonstrate the similar character of all the ion series more clearly, they are plotted in Figure S2 as a function of the number of water molecules $n$ in the $\mathrm{X} \cdot\left(\mathrm{HNO}_{3}\right)_{m}\left(\mathrm{H}_{2} \mathrm{O}\right)_{n}{ }^{+}$ions. The plots are arranged as in Figure $S 1$ (except for $\alpha$-pinene). 


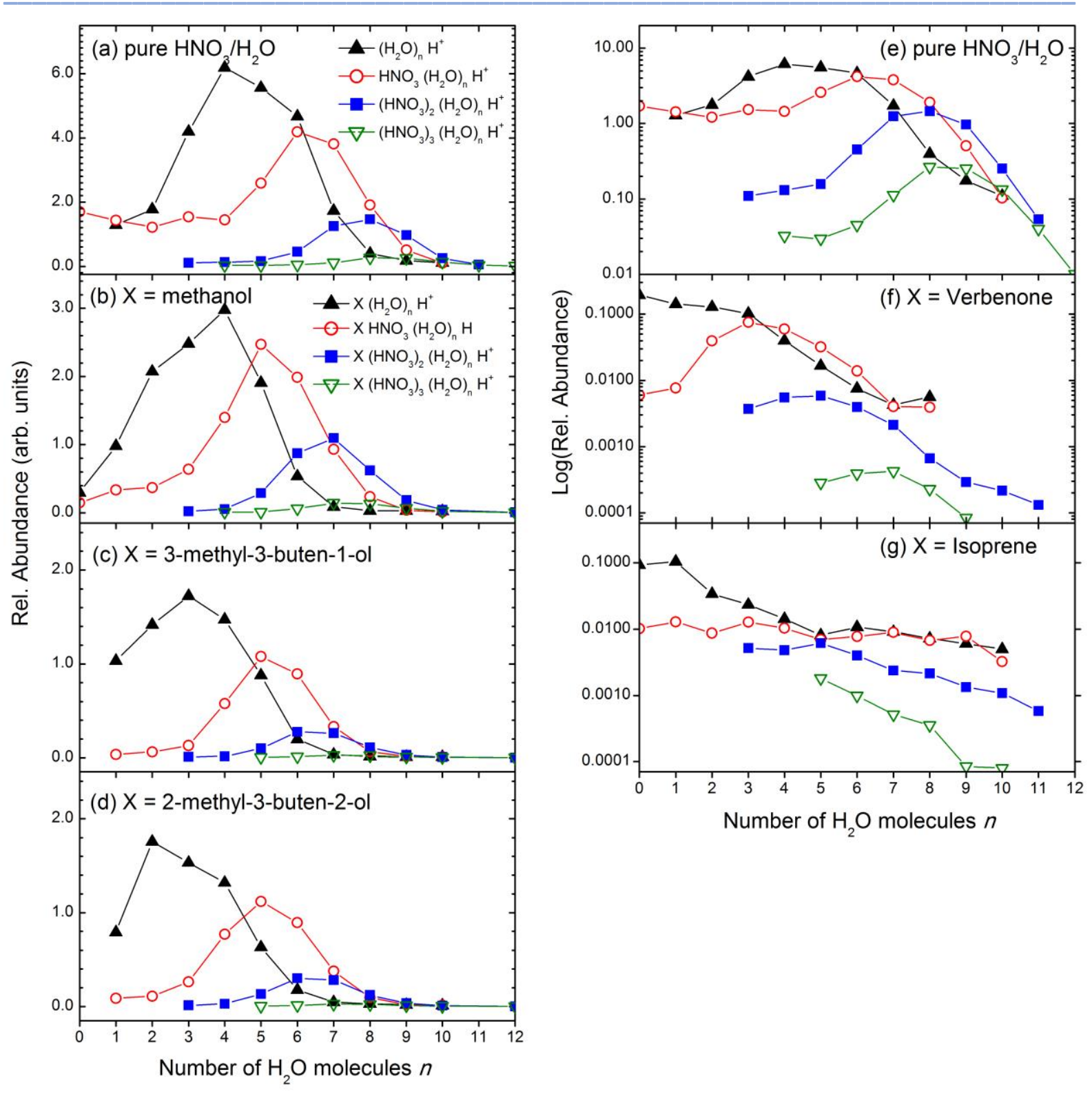

Figure S2: lon series of $\mathrm{X} \cdot\left(\mathrm{HNO}_{3}\right)_{m}\left(\mathrm{H}_{2} \mathrm{O}\right)_{n} \mathrm{H}^{+}$as a function of the number of water molecules $n$.

The clusters which did not pick up the molecule $X$ can still undergo some elastic (and inelastic) collisions in the pickup cell (see also below) which can deflect them from the cluster beam. Indeed, the intensities of the $\left(\mathrm{HNO}_{3}\right)_{m}\left(\mathrm{H}_{2} \mathrm{O}\right)_{n} \mathrm{H}^{+}$ions in the pickup spectra are depleted with respect to the same mass peaks in the pure cluster spectra without pickup (typically, the pickup pressure was adjusted so that the intensities decreased by roughly 1/3-1/2). The intensities of small fragment ions (originating from smaller neutral clusters) are depleted more by scattering than the larger ones. Therefore, the pickup spectra should be corrected by a mass-dependent scattering function in order to compare the peak intensities with the mass peaks in the pure spectra without any pickup gas. We compare all the $\left(\mathrm{HNO}_{3}\right)_{m}\left(\mathrm{H}_{2} \mathrm{O}\right)_{n} \mathrm{H}^{+}$peaks in the spectra with the pickup of molecules to the same peaks in the spectra of pure $\left(\mathrm{HNO}_{3}\right)_{M}\left(\mathrm{H}_{2} \mathrm{O}\right)_{N}$ clusters without pickup, and fit their ratio by a polynomial function. This 
represents the correction function for the pickup spectra, which takes into account the beam deflection in the pickup cell. Figure S3 shows an example of the scattering correction function for the case of 2-methyl-3-buten-2-ol. About $10 \%$ of the small clusters which contribute to the small mass fragments remain in the beam and reach the detector when the scattering gas is added into the pickup cell. The function is slowly increasing, and only for the largest detected cluster fragments the fraction of non-scattered contributing clusters reaches about $40 \%$. We have obtained similar correction functions in the experiments with all the pickup gasses. Figure $\mathrm{S} 1$ shows the raw uncorrected mass spectra, while in Figure S2 the scattering correction function has already been considered. It ought to be stressed, that the implementation of the correction function has actually no effect on the evaluation of the pickup probability as outlined below.

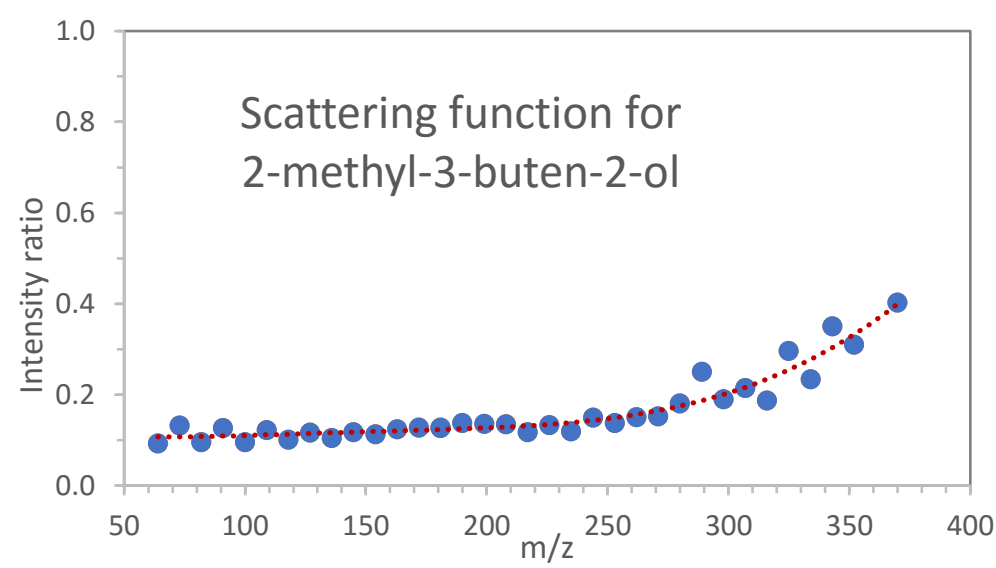

Figure S3: The scattering correction function for the case of 2-methyl-3-buten-2-ol.

\section{III. b) Velocity measurements for $\mathrm{MeOH}$}

Based on the shape of the spectra, we suggested that the pure $\left(\mathrm{HNO}_{3}\right)_{m}\left(\mathrm{H}_{2} \mathrm{O}\right)_{n} \mathrm{H}^{+}$series in the pickup spectra originated from the pure $\left(\mathrm{HNO}_{3}\right)_{M}\left(\mathrm{H}_{2} \mathrm{O}\right)_{N}$ clusters which did not pick up any molecule $X$. However, we have to exclude the possibility that the $\left(\mathrm{HNO}_{3}\right)_{m}\left(\mathrm{H}_{2} \mathrm{O}\right)_{n} \mathrm{H}^{+}$fragments originate from $\mathrm{X} \cdot\left(\mathrm{HNO}_{3}\right)_{M}\left(\mathrm{H}_{2} \mathrm{O}\right)_{N}$ clusters from which the molecule $\mathrm{X}$ evaporated upon the ionization. This was proved by measuring the cluster velocity as described in detail in our paper on methanol pickup. ${ }^{1}$

Briefly, a supersonic expansion results in relatively narrow velocity distribution of all clusters and molecules in the beam independent of their size. In the present case the measured cluster velocity peaked around $v_{0}=1801 \mathrm{~ms}^{-1}$ with $\Delta v_{0} \approx 80 \mathrm{~ms}^{-1} \mathrm{FWHM}$ (full width at half maximum). The clusters undergoing sticking collisions with molecules $X$ are slowed down by momentum transfer. The cluster velocity is large compared to the Boltzmann distribution of thermal velocities of molecules $X$ in the pickup chamber (e.g., their distribution 
peaks at $400 \mathrm{~ms}^{-1}$ for methanol, and even lower for heavier molecules). In addition, the molecule velocities are randomly oriented. Therefore we can assume clusters with the speed $v_{0}$ colliding with stationary target molecules. For a sticking collision, the momentum transfer yields a cluster velocity $v=v_{0} \cdot \frac{m_{C}}{m_{C}+m_{X}}$ after the collision $\left(m_{C}\right.$ and $m_{X}$ are the cluster and molecule masses, respectively, and we assume no cluster excitation, i.e. hard sphere collisions). Thus we can determine if the cluster picked up a molecule by an accurate measurement of the cluster velocity. If the velocity measured at the mass of an ion fragment $\left(\mathrm{HNO}_{3}\right)_{m}\left(\mathrm{H}_{2} \mathrm{O}\right)_{n} \mathrm{H}^{+}$were smaller than $v_{0}$, we can conclude that a molecule was picked up by the cluster yielding $\mathrm{X} \cdot\left(\mathrm{HNO}_{3}\right)_{M}\left(\mathrm{H}_{2} \mathrm{O}\right)_{N}$, and the molecule evaporated upon the ionization. The velocities measured for $\mathrm{X} \cdot\left(\mathrm{HNO}_{3}\right)_{m}\left(\mathrm{H}_{2} \mathrm{O}\right)_{n} \mathrm{H}^{+}$fragments are clearly significantly lower than $v_{0}$, see Figure S4. On the other hand, the velocity measurements performed on all mass peaks corresponding to the pure $\left(\mathrm{HNO}_{3}\right)_{m}\left(\mathrm{H}_{2} \mathrm{O}\right)_{n} \mathrm{H}^{+}$fragment ions resulted essentially in $v_{0}$. Black triangles correspond to velocities measured on the different $\left(\mathrm{HNO}_{3}\right)_{m}\left(\mathrm{H}_{2} \mathrm{O}\right)_{n} \mathrm{H}^{+}$fragment ions without any gas in the pickup cell. Open blue circles correspond to velocities measured on these $\left(\mathrm{HNO}_{3}\right)_{m}\left(\mathrm{H}_{2} \mathrm{O}\right)_{n} \mathrm{H}^{+}$fragment ions when the pickup cell was filled with methanol gas. There is a slight shift in the velocities with the pickup gas possibly due to inelastic collisions (but no sticking collisions) in the pickup cell. Nevertheless, all these velocities do not depend significantly on mass and correspond to $v_{0}$. On the contrary, velocities measured for $\mathrm{CH}_{3} \mathrm{OH} \cdot\left(\mathrm{HNO}_{3}\right)_{m}\left(\mathrm{H}_{2} \mathrm{O}\right)_{n} \mathrm{H}^{+}$fragments (red circles) are significantly shifted to lower values and exhibit increasing tendency with the fragment mass. The same holds for velocities measured for $\mathrm{X} \cdot\left(\mathrm{HNO}_{3}\right)_{m}\left(\mathrm{H}_{2} \mathrm{O}\right)_{n} \mathrm{H}^{+}, \mathrm{X}=3$-methyl-3-buten-1-ol (purple diamonds) and 2-methyl-3-buten-2ol (green squares). They are shifted even more with respect to $v_{0}$ due to the higher mass of these molecules compared to methanol (and thus larger momentum transfer). Their mass is identical, therefore the shift is the same for both these molecules. The velocities could be measured reliably only for some $\mathrm{X} \cdot\left(\mathrm{HNO}_{3}\right)_{m}\left(\mathrm{H}_{2} \mathrm{O}\right)_{n} \mathrm{H}^{+}$fragments due to a mass spectrum congestion and low mass resolution of our quadrupole (in contrary to a high mass resolution of our TOF that, however, does not allow for the velocity measurements). The mass peaks where pure $\left(\mathrm{HNO}_{3}\right)_{m}\left(\mathrm{H}_{2} \mathrm{O}\right)_{n} \mathrm{H}^{+}$and doped $\mathrm{X} \cdot\left(\mathrm{HNO}_{3}\right)_{m}\left(\mathrm{H}_{2} \mathrm{O}\right)_{n} \mathrm{H}^{+}$cluster mass peaks overlap could not be used in the velocity measurements. Nevertheless, the shifts are unambiguous and consistent with the momentum transfer, and they prove that the ion fragments $\left(\mathrm{HNO}_{3}\right)_{m}\left(\mathrm{H}_{2} \mathrm{O}\right)_{n} \mathrm{H}^{+}$originate from pure $\left(\mathrm{HNO}_{3}\right)_{M}\left(\mathrm{H}_{2} \mathrm{O}\right)_{N}$ clusters, which passed through the pickup cell without adsorbing any molecule. 


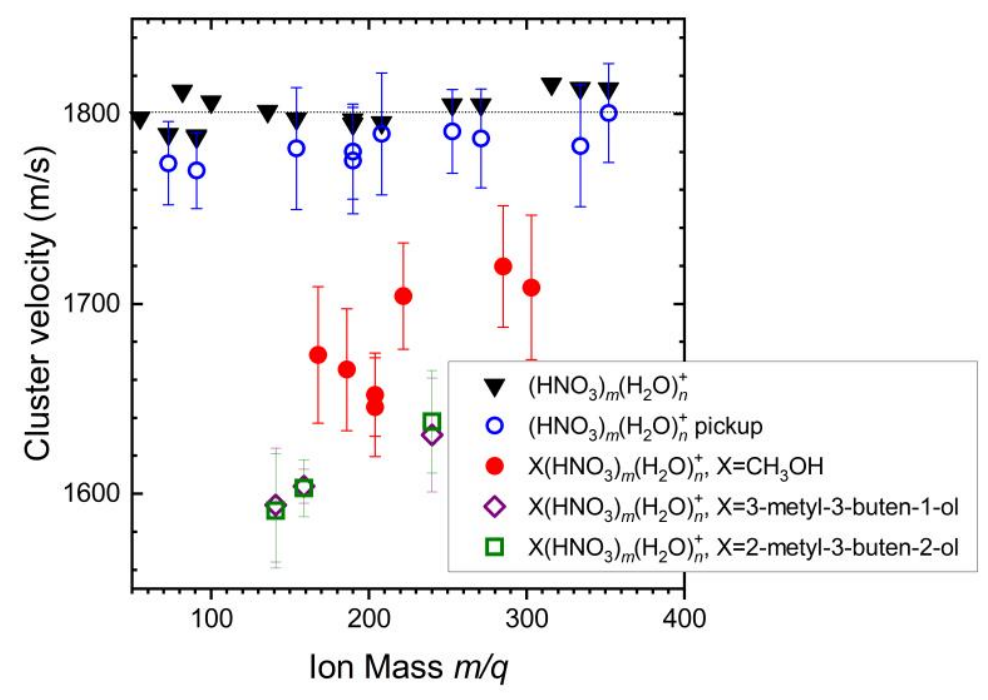

Figure S4: Cluster velocities measured on different $\left(\mathrm{HNO}_{3}\right)_{m}\left(\mathrm{H}_{2} \mathrm{O}\right)_{n} \mathrm{H}^{+}$fragment ions without any gas in the pickup cell (black triangles) corresponding to the beam velocity $v_{0}=1801 \mathrm{~ms}^{-1}$. Velocities measured on the same $\left(\mathrm{HNO}_{3}\right)_{m}\left(\mathrm{H}_{2} \mathrm{O}\right)_{n} \mathrm{H}^{+}$fragment ions when the pickup cell was filled with methanol gas (open blue circles), and velocities measured for $\mathrm{CH}_{3} \mathrm{OH} \cdot\left(\mathrm{HNO}_{3}\right)_{m}\left(\mathrm{H}_{2} \mathrm{O}\right)_{n}{ }^{+}$fragments (closed red circles). Velocities measured for $\mathrm{X} \cdot\left(\mathrm{HNO}_{3}\right)_{m}\left(\mathrm{H}_{2} \mathrm{O}\right)_{n} \mathrm{H}^{+}, \mathrm{X}=3$ 3-methyl-3-buten-1-ol (purple diamonds) and 2methyl-3-buten-2-ol (green squares).

\section{III c) Pickup probability}

This subsection shows how we evaluated the pickup probabilities $f$ from the intensities of the measured ion series $\mathrm{X} \cdot\left(\mathrm{HNO}_{3}\right)_{m}\left(\mathrm{H}_{2} \mathrm{O}\right)_{n} \mathrm{H}^{+}$shown in Figure S2. The doped $\mathrm{X} \cdot\left(\mathrm{HNO}_{3}\right)_{m}\left(\mathrm{H}_{2} \mathrm{O}\right)_{n} \mathrm{H}^{+}$ and pure $\left(\mathrm{HNO}_{3}\right)_{m}\left(\mathrm{H}_{2} \mathrm{O}\right)_{n} \mathrm{H}^{+}$series correspond to the clusters which passed the pickup cell with and without adsorbing any molecule, respectively. Note that a mass peak intensity is a product of the cluster flux, and the ionization and ion detection probabilities. Here we can plausibly assume that the ionization and detection probabilities of the pure and doped clusters are the same, because of the high energy of ionizing electrons of $70 \mathrm{eV}$.

The velocity measurements above proved that the $\left(\mathrm{HNO}_{3}\right)_{m}\left(\mathrm{H}_{2} \mathrm{O}\right)_{n} \mathrm{H}^{+}$fragments originated from clusters which did not pick up any $X$ molecules. However, these clusters could still undergo some non-sticking collisions. If these were elastic collisions, the corresponding momentum transfer would be even larger than in the case of sticking collisions and the corresponding measured velocities would be even smaller. Since this is not the case, the nonsticking collisions have to correspond to some impacts at grazing angles which do not lead to a significant momentum transfer and thus to a cluster velocity change. Also inelastic collisions can be considered where the momentum is transferred to individual cluster constituents and 
thus to the cluster internal energy (i.e. intermolecular vibrations) but the velocity of the cluster as a whole does not change.

Thus the clusters with velocities close to $v_{0}$ either passed through the pickup cell without any collision or underwent some non-sticking collisions without a significant momentum transfer. To determine the importance of these two sources, we estimate below the number of collisions the clusters undergo with molecules in the pickup chamber:

$$
N_{\text {col }}=\sigma_{c} \cdot L \cdot n_{p}
$$

where $L$ is the path-length of the beam in the pickup cell and $n_{p}$ is the pickup gas density (obtained from the gas pressure $p_{p}$ ). In the first approximation, the collision cross section $\sigma_{c}$ can be substituted by the geometrical cross section $\sigma_{g}$ estimated from theoretically calculated cluster geometry. We have outlined this estimate in our previous publication on methanol pickup. ${ }^{1}$ Rigorously, a cluster size distribution should be considered, however, we consider an average-size from the present cluster size distribution, $\mathrm{HNO}_{3} \cdot\left(\mathrm{H}_{2} \mathrm{O}\right)_{6}$. The geometrical cross section of this cluster corresponds roughly to $\sigma_{g} \approx 60 \AA^{2}$. Thus for $L=17 \mathrm{~cm}$ and a typical pickup pressure $p_{p} \approx 8 \times 10^{-4} \mathrm{mbar}$, the average number of collisions for a cluster in the pickup cell is $N_{c o l} \approx 2$. This is rather a lower estimate for two reasons: First, the geometrical cross section $\sigma_{g}$ includes also the "size" of the molecule (the molecular radius enters $\sigma_{g}$ in the second power) which is larger than methanol for all concerned molecules (see below). Second, our previous pickup experiments ${ }^{6}$ showed that the actual collision cross section $\sigma_{c}$ can be significantly larger than the geometrical cross section $\sigma_{g}$ due to attractive dipole molecule-cluster interactions.

Based on the above rough estimate of the average collision number, we can assume that under our experimental conditions essentially each cluster collides with a molecule $X$ at least once in the pickup cell. The sticking collisions then lead to $X \cdot\left(\mathrm{HNO}_{3}\right)_{M}\left(\mathrm{H}_{2} \mathrm{O}\right)_{N}$, that yield the $\mathrm{X} \cdot\left(\mathrm{HNO}_{3}\right)_{m}\left(\mathrm{H}_{2} \mathrm{O}\right)_{n} \mathrm{H}^{+}$fragment ions after the ionization. On the other hand, the $\left(\mathrm{HNO}_{3}\right)_{M}\left(\mathrm{H}_{2} \mathrm{O}\right)_{N}$ clusters undergoing non-sticking collisions yield the $\left(\mathrm{HNO}_{3}\right)_{m}\left(\mathrm{H}_{2} \mathrm{O}\right)_{n} \mathrm{H}^{+}$ fragment ions. Thus, the pickup probability $f$, i.e., the ratio of sticking collisions and all collisions, can be expressed as:

$$
f=\frac{I_{X}}{I_{X}+I_{C}}
$$

where $I_{X}$ is the integrated intensity of all $X \cdot\left(\mathrm{HNO}_{3}\right)_{m}\left(\mathrm{H}_{2} \mathrm{O}\right)_{n} \mathrm{H}^{+}$fragment ions, and $I_{C}$ is the integrated intensity of $\left(\mathrm{HNO}_{3}\right)_{m}\left(\mathrm{H}_{2} \mathrm{O}\right)_{n} \mathrm{H}^{+}$fragment ions. Since both $I_{x}$ and $I_{C}$ are evaluated from the same spectrum, it does not matter whether the spectrum was corrected using the scattering correction function defined above. Both series would be simply multiplied by the same factor, which would cancel out in their ratio. In other words, our method of determination of the pickup 
probability is essentially independent of the deflection processes. The evaluated pickup probabilities are summarized in Table S1.

It ought to be mentioned that for pinene pickup there are no series shown in Figure S2. Nevertheless, some peaks at masses corresponding to $\mathrm{X} \cdot\left(\mathrm{HNO}_{3}\right)_{m}\left(\mathrm{H}_{2} \mathrm{O}\right)_{n} \mathrm{H}^{+}$ions could be identified in the spectrum. Therefore, we use the same evaluation procedure as above using theses mass peak intensities and denote the obtained value as an upper limit for the pickup probability for pinene.

Table S1: Pickup probabilities $f$, scaling factors $k$ accounting for mass and molecule radius, pickup probabilities normalized to methanol $\phi$ and relative pickup probability scalled by the $k$ values $\phi^{s c}$. Experimental error bars on $f$ (in parenthesis) correspond to statistical error of repeated measurements, however, considering all experimental uncertainties may result in error bars up to $10 \%$ of the measured values.

\begin{tabular}{|c|c|c|c|c|c|c|c|}
\hline Molecule & $f$ & $R(\AA)$ & $k_{R}$ & $m(\mathrm{amu})$ & $k_{m}$ & $\phi$ & $\phi^{s c}$ \\
\hline methanol & $0.369(5)$ & 2.33 & & 32 & & 1 & 1 \\
\hline 3-methyl-3-buten-1-ol & $0.170(4)$ & 3.22 & 1.32 & 86 & 1.29 & 0.460 & 0.447 \\
\hline 2-methyl-3-buten-2-ol & $0.172(4)$ & 3.20 & 1.31 & 86 & 1.29 & 0.468 & 0.458 \\
\hline isoprene & $0.007(3)$ & 3.07 & 1.26 & 68 & 1.22 & 0.019 & 0.018 \\
\hline verbenone & $0.014(4)$ & 3.69 & 1.51 & 150 & 1.44 & 0.038 & 0.036 \\
\hline$\alpha$-pinene & $<0.002$ & 3.69 & 1.51 & 136 & 1.41 & $<0.006$ & 0.006 \\
\hline
\end{tabular}

It should be considered, that the collisions of the clusters with molecules follows a certain distribution, and some clusters can pass through the pickup cell without any collisions with the pickup gas at all. Such collisions would systematically lower our evaluated pickup probability, therefore we estimate their effect below. It is well established that the collisions of clusters with molecules in a pickup cell follow Poisson distribution. ${ }^{5,20-22}$ Thus the probability, that a cluster collides with $k$ molecules at a pickup pressure $p_{x}$ is given by the Poisson formula:

$$
P_{k}\left(p_{X}\right)=\frac{1}{k !}\left(a \cdot p_{X}\right)^{k} \cdot e^{-a \cdot p_{X}}
$$

where the constant $\alpha$ is determined by the cluster collision cross section $\sigma$, the length of the collision cell $L=17 \mathrm{~cm}$, and the gas temperature $T=300 \mathrm{~K}$ ( $k_{B}$ is the Boltzmann constant): 


$$
a=\frac{\sigma \cdot L}{k_{B} \cdot T}
$$

For our current conditions, assuming geometrical cross section $\sigma_{g} \approx 60 \AA^{2}$, we obtain the $P_{k}$ probabilities depicted in Figure S5. In the range of pressures $8-10 \times 10^{-4}$ mbar used in our experiments (indicated by the grey arrows), the probability of $k=0$ collisions is around $10 \%$.

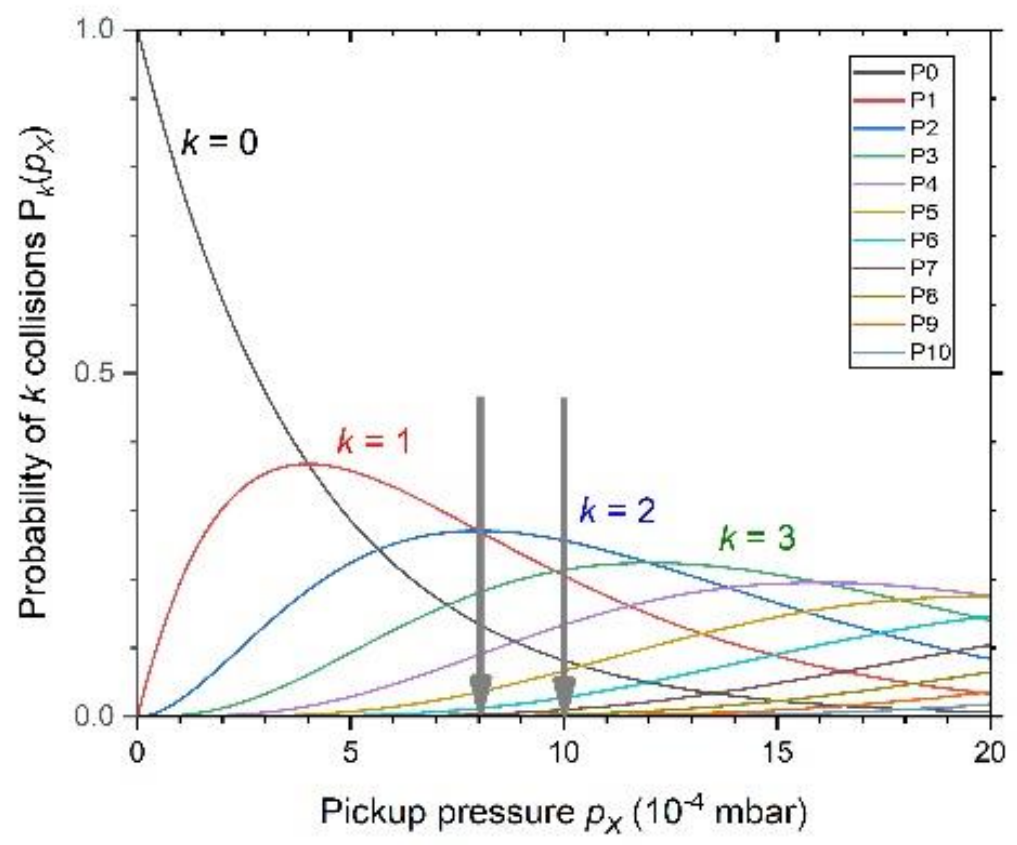

Figure S5: Poisson distribution corresponding to $k$ collisions of a clusters with molecules in a pickup cell at a pickup gas pressure $p_{x}$. The distribution was calculated for a cluster cross section $\sigma \approx 60 \AA^{2}$. The arrows indicate experimentally relevant pickup pressure range. 8-10×10-4 mbar.

In reality, this fraction is even smaller. First, the geometrical cross section above is rather conservative estimate and the real collision cross section will certainly be larger as discussed above. This will increase the number of collisions and lower the fraction of the clusters, which did not undergo any collision $P_{0}$. Second, we have an experimental evidence that even the clusters, which yield the "clean" $\left(\mathrm{HNO}_{3}\right)_{m}\left(\mathrm{H}_{2} \mathrm{O}\right)_{n} \mathrm{H}^{+}$peaks in the mass spectra, also undergo some collisions in the pickup cell. These are not the sticking collisions (the full momentum of the molecule is not transferred), yet there is a small but systematic lowering in the cluster velocity corresponding to these peaks. We have attributed this small change in cluster velocity to grazing and inelastic collisions as discussed above. This shift is observed for all the "clean" mass peaks, and thus all the detected clusters probably underwent these collisions. In summary, the effect of the clusters passing through the pickup cell without any collisions on our evaluated pickup probabilities will be significantly below $10 \%$. 


\section{III d) Scaled pickup probability}

The evaluated pickup probabilities depend on properties of the adsorbed molecules; in particular on their molecular masses (relative kinetic energy in collision with the cluster) and geometrical sizes (radii) of the molecules. Since these are intrinsic properties of the molecules, they have to be included inherently in the absolute values of the measured pickup probabilities. However, for the sake of comparison between individual molecules, we can extract relative values of pickup probabilities, and then account for the molecular parameters. For this purpose, we relate the pickup probabilities to the one for methanol, getting the relative pickup probabilities $\varphi(X)=\frac{f(X)}{f\left(\mathrm{CH}_{3} \mathrm{OH}\right)}$ which is $\varphi\left(\mathrm{CH}_{3} \mathrm{OH}\right)=1$ for methanol, see Table S1.

First, we account for the effect of the size of adsorbed molecules. The pickup probability is proportional to the pickup cross section $\sigma_{c}$ which in turn is proportional (not equal, see Refs. ${ }^{5-7}$ ) to the geometrical cross section, $\sigma_{c} \propto \sigma_{g}$. The geometrical cross section can be approximated as $\sigma_{g}=\pi\left(R_{C}+R_{X}\right)^{2}$ where $R_{C}$ and $R_{X}$ are the radii of the cluster and the molecule, respectively. To account for the different molecular radii $R_{X}$, we can scale the relative pickup probability $\varphi(X)$ by a factor $k_{R}$ corresponding to the ratio of the geometrical cross sections for the pickup of methanol and the molecule $k_{R}=\frac{\sigma_{g}\left(\mathrm{CH}_{3} \mathrm{OH}\right)}{\sigma_{g}(\mathrm{X})}$, i.e. $k_{R}=\left(\frac{R_{C}+R_{\mathrm{CH}_{3} \mathrm{OH}}}{R_{C}+R_{X}}\right)^{2}$. A cluster radius of $R_{C}=3.62 \AA$ was calculated for the average cluster size used in the present experiments which corresponded to the acidically dissociated structure of $\mathrm{HNO}_{3} \cdot\left(\mathrm{H}_{2} \mathrm{O}\right)_{6}$ cluster. The molecular radii in Table S1 were calculated from molecular volumes computed using MonteCarlo integration available in Gaussian 09. ${ }^{17}$

Second factor influencing the pickup probability is the mass of the adsorbed molecule. Actually, the pickup cross section depends on the relative kinetic energy in the cluster-molecule collisions, and the mass of the molecule determines the collision energy, which is given as: $T_{r e l}=\frac{\mu \cdot g^{2}}{2}$, where $g$ is the relative collision velocity and $\mu$ is the reduced mass $\mu=\frac{m_{C} \cdot m_{X}}{m_{C}+m_{X}}, m_{C}$ and $m_{X}$ are the cluster and molecular masses, respectively. The cluster mass $m_{C}=171 \mathrm{amu}$ was taken for the average $\mathrm{HNO}_{3} \cdot\left(\mathrm{H}_{2} \mathrm{O}\right)_{6}$ cluster as above. The collision cross section scales with $T_{r e l}^{-1 / 3} \cdot{ }^{23}$ In the case of the cluster-molecule collisions, the relative velocity $g$ is dominated by the cluster velocity produced in the supersonic expansion, $v_{0}=1801 \mathrm{~ms}^{-1}$ (see above). The velocities of molecules in the pickup cell correspond to Boltzmann distribution at about $300 \mathrm{~K}$, and are thus significantly lower (typically $300 \mathrm{~ms}^{-1}$ ). Besides they are randomly oriented. Therefore we can approximate the relative velocity $g$ by the cluster velocity $v_{0}$, and thus it will be the same for all the molecules. As a result, the scaling is proportional only to the reduced 
mass, and the scaling factor will be $k_{m}=\left(\frac{\mu_{\mathrm{CH}_{3} \mathrm{OH}}}{\mu_{X}}\right)^{1 / 3}$ for the mass scaled relative pickup probability $\varphi(X) / k_{m}$.

Table S1 summarizes the molecular parameters and corresponding scaling factors $k_{R}$ and $k_{m}$. Accidentally, $k_{R}$ and $k_{m}$ turned out very close for all the studied molecules, and thus essentially cancel out in the overall correction of the relative pickup probabilities: $\varphi^{s c}(X)=\frac{k_{R}}{k_{m}} \cdot \varphi(X)$. The physical meaning of $\varphi^{s c}(X)$ values is that they represent pickup probabilities normalized to the methanol value and take into account the size-related molecular parameters. In other words, the intrinsic parameters of the molecules (their mass and size) are factored out in the relative pickup probabilities $\varphi^{s c}(X)$ and we compare only the relative pickup probability determined by the character of the interaction of the molecule with the cluster.

\section{PICKUP PROBABILITY AND UPTAKE COEFFICIENT}

Results of our present pickup experiments with clusters are expressed in terms of a pickup probability $f$. In atmospheric chemistry, bulk surface properties such as uptake coefficient $\gamma$, surface (or mass) accommodation coefficient $\alpha_{S}$, and sticking (or adsorption) coefficient $S$ are usually used in modeling of heterogeneous processes. ${ }^{24}$ In this paragraph, we outline the relationship between our measured pickup probability $f$ and the corresponding bulk properties.

The uptake coefficient $\gamma$ is the net probability that a molecule $X$ undergoing a collision with the surface is actually taken up at the surface as defined by a first order kinetic equation:24

$$
\frac{d[X]_{g}}{d t}=-\gamma \frac{\bar{c} \cdot A}{4}[X]_{g}
$$

where $[X]_{g}$ denotes the gas phase concentration of molecules, $A$ is the condensed phase surface area, and $\bar{c}$ is the mean thermal velocity of gas $X$. Thus the factor $\frac{\bar{c} \cdot A}{4}[X]_{g}$ corresponds to the number of molecules $X$ colliding with the surface area $A$. This equation suggests that the simplest way to determine $\gamma$ is to measure an apparent loss of $X$ from the gas phase above a bulk surface. However, in reality $\gamma$ often changes with time and depends on the gas phase concentration $[X]_{g}$. Besides, other factors such as adsorption equilibrium on the surface, solubility of $X$ in the bulk, reactions in the bulk, etc. have to be considered. A comprehensive overview of possible processes can be found in various reviews, e.g. Refs. ${ }^{25-28}$. All these processes can complicate any measurement of an actual uptake coefficient and, therefore individual contributions have to be well-defined and treated separately.

Let us now focus on the description of surface accommodation which is given by a difference between the rates of adsorption and desorption: 


$$
-\frac{d[X]_{g}}{d t}=\alpha_{S} \frac{\bar{c} \cdot A \cdot(1-\theta)}{4}[X]_{g}-k_{d e s} \cdot[X]_{S} \cdot A,
$$

where $\alpha_{S}$ is the surface accommodation coefficient, $\theta$ is the surface coverage and $k_{\text {des }}$ is the rate constant of desorption. The characteristic times associated with the processes are the following. A molecule colliding with a bulk surface (solid or liquid) can undergo an elastic or inelastic scattering on time scales up to $1 \mathrm{ps}$. Accommodation of the molecule into a weakly bound state on the surface (e.g. via hydrogen bonds or Van der Waals interactions) is referred to as adsorption or physisorption. The molecule can be released again from the adsorbed state through a thermally activated desorption. Lifetimes of adsorbed molecules are typically nanoseconds to seconds.

The connection between the coefficients originally defined for macroscopic bulk surface and our present cluster experiment is relatively simple. Our clusters move through the pickup gas under extremely diluted concentration (essentially in a high vacuum) undergoing only a few collisions within the pickup chamber. Thus, we can neglect any diffusion in the gas due to the gas concentration gradient near the surface, which becomes an issue for large $\gamma$ at high $[X]_{g}$ concentrations. ${ }^{25}$ There are no chemical reactions considered for our present molecules on $\left(\mathrm{HNO}_{3}\right)_{M}\left(\mathrm{H}_{2} \mathrm{O}\right)_{N}$ clusters, and the adsorbed molecules do not dissolve nor diffuse into the cluster interior due to the small size of our clusters. Essentially, we investigate an adsorption of a single molecule on the cluster surface in vacuum. In addition, we can only observe processes occurring on relatively short time-scale of our experiments, which corresponds to the cluster flight-time from the pickup chamber to the ionization region of our TOF detector that is of the order of $1 \mathrm{~ms}$. Therefore, only scattering and adsorption processes are relevant in our experiments. For this special case we can simply relate $f$ to $\alpha_{s}$.

Surface accommodation is traditionally investigated for macroscopic bulk surfaces in molecular details by directing a molecular beam on surface in ultrahigh vacuum, see e.g. Refs. 29-32. These experiments bear some similarities with our cluster investigations, although, in our case, a beam of clusters representing the adsorption surface moves through a quasi-stationary gas (the beam velocity is directional and much larger than the randomly oriented thermal velocity of the gas molecules, see above).

Unfortunately, to our best knowledge, no bulk measurements of the above coefficients have been reported for adsorption of the molecules used in our experiments on nitric acidwater ice. Therefore we cannot compare our cluster measurements with any bulk surface experiment. Such comparison would be illustrative, since the small clusters can be relevant for molecular uptake by atmospheric aerosols - in some respect even more relevant than the macroscopic bulk ice measurements. Especially, since the small aerosols and clusters of $1 \mathrm{~nm}$ and even sub-nanometer dimensions are being discovered in large quantities in the 
atmosphere as the detection sensitivity and resolution of atmospheric experiments increases. ${ }^{33}$ The new discoveries also emphasize the role of the small particles played in atmospheric processes and aerosol nucleation.

It ought to be stressed that our pickup probability is a genuinely and purely kinetic parameter, which does not envolve any evaporation of the adsorbed molecules from the cluster surface. In our case of a molecular beam in vacuum, there is no equilibrium between the cluster and a vapor. After the clusters are generated in the supersonic expansion, they fly in the vacuum without any further evaporation or interaction with other molecules. In the pickup chamber, the clusters can collide with molecules of much diluted pickup gas $\left(\sim 10^{-4}-10^{-3}\right.$ mbar, corresponding to the mean free path of the molecules $\sim 10-100 \mathrm{~cm})$. Upon a sticking collision with a molecule $\mathrm{X}$, some energy can be deposited into the cluster corresponding to the centerof-mass collision energy plus the binding energy of the molecule. The former is given by $T_{c o l}=$ $\frac{1}{2} \mu v^{2}$, which corresponds to $\approx 0.4 \mathrm{eV}$ (for methanol). The binding energies are given in Table 1 in the main article and correspond to $\approx 0.5 \mathrm{eV}$ at most. Thus, the energy deposited in the cluster upon the sticking collision could evaporate 1 or 2 water molecules. However, our velocity measurements above show that after the sticking collision, the picked-up molecule $\mathrm{X}$ remains attached to the cluster for another $0.84 \mathrm{~ms}$ of its flight time to the detector. If an adsorbed molecule would evaporate from the cluster before reaching the detector, the corresponding cluster fragment without the molecule $\left(\mathrm{HNO}_{3}\right)_{m}\left(\mathrm{H}_{2} \mathrm{O}\right)_{n} \mathrm{H}^{+}$would still have a lower velocity due to the momentum transfer upon the uptake of the molecule. We do not observe such fragment, all the "clean" $\left(\mathrm{HNO}_{3}\right)_{m}\left(\mathrm{H}_{2} \mathrm{O}\right)_{n} \mathrm{H}^{+}$fragments have essentially unperturbed velocities, as discussed above. Therefore, there is no evaporation of $X$ from the cluster, only adsorption, and our measured $\alpha_{\mathrm{S}}$ is purely kinetically determined quantity.

\section{THEORETICAL RESULTS}

Table S2 summarizes binding energies $\left(-\Delta E_{B}\right)$ of VOCs to the $\mathrm{HNO}_{3}\left(\mathrm{H}_{2} \mathrm{O}\right)_{6}$ cluster evaluated using different methods. $\Delta E_{B}$ is the following energy difference $\Delta E_{B}=E\left(\mathrm{X} \cdot \mathrm{HNO}_{3}\left(\mathrm{H}_{2} \mathrm{O}\right)_{6}\right)-$ $E\left(\mathrm{HNO}_{3}\left(\mathrm{H}_{2} \mathrm{O}\right)_{6}\right)-E(\mathrm{X})$, where the complexes are in their minimum energy configuration. The optimization and the zero-point vibrational energy calculation were performed employing the M06-2X/aug-cc-pVDZ method in all cases. $\Delta E_{B}$ was counter-poise corrected for the basis set superposition error in the rigid monomer scheme.

Results of the M06-2X/aug-cc-pVDZ method are in a good agreement with the MP2/aug-cc-pVTZ. The binding energies of the alcohols calculated by the DFT method (45 $\left.52 \mathrm{~kJ} \cdot \mathrm{mol}^{-1}\right)$ are slightly higher than those calculated by MP2 $\left(39-49 \mathrm{~kJ} \cdot \mathrm{mol}^{-1}\right)$. The same 
trend holds for the non-polar compounds, the binding energies of isoprene and pinene evaluated at the DFT level $\left(24 \mathrm{~kJ} \cdot \mathrm{mol}^{-1}\right.$ and $10.5 \mathrm{~kJ} \cdot \mathrm{mol}^{-1}$, resp.) are by $3 \mathrm{~kJ} \cdot \mathrm{mol}^{-1}$ and $4.5 \mathrm{~kJ} \cdot \mathrm{mol}^{-1}$, resp. higher than those at the MP2 level. It was computationally feasible to evaluate the $\operatorname{CCSD}(\mathrm{T})$ biding energies only for the isoprene-derived compounds and methanol. $\operatorname{CCSD}(\mathrm{T})$ values are somewhat lower than the MP2 ones, but for the four available molecules, they also predict the strongest biding for 2-methyl-3-buten-2-ol and the weakest for isoprene, the difference between them is $27-28 \mathrm{~kJ} \cdot \mathrm{mol}^{-1}$.

Table S2: Binding energies $\left(-\Delta E_{B}\right)$ in $\mathrm{kJ} \mathrm{mol}^{-1}$ of VOCs to the $\mathrm{HNO}_{3}\left(\mathrm{H}_{2} \mathrm{O}\right)_{6}$ cluster evaluated using different methods: M06-2X, MP2, $\operatorname{CCSD}(T)$ and basis sets: aug-cc-pVDZ and aug-ccpVTZ abbreviated as DZ and TZ

\begin{tabular}{|c|c|c|c|}
\hline Molecule $/-\Delta E_{B}\left(\mathrm{~kJ} \cdot \mathrm{mol}^{-1}\right)$ & M06-2X/DZ & MP2/TZ & $\operatorname{CCSD}(T) / D Z$ \\
\hline Methanol & 45.9 & 44.4 & 39.0 \\
\hline 3-methyl-3-buten-1-ol & 45.6 & 39.0 & 28.3 \\
\hline 2-methyl-3-buten-2-ol & 52.0 & 48.6 & 41.6 \\
\hline Isoprene & 24.0 & 21.2 & 14.3 \\
\hline Verbenone & 40.6 & 51.1 & \\
\hline$\alpha$-pinene & 10.5 & 5.9 & \\
\hline
\end{tabular}

Nitric acid in the clusters with 6 water molecules preferentially appears in the acidicaly dissociated form. This is illustrated in Figure $\mathrm{S} 6$ which depicts the lowest energy dissociated and the lowest energy neutral structure of $\mathrm{HNO}_{3}\left(\mathrm{H}_{2} \mathrm{O}\right)_{6}(\mathrm{a}, \mathrm{b})$ and $\mathrm{CH}_{3} \mathrm{OH} \cdot \mathrm{HNO}_{3}\left(\mathrm{H}_{2} \mathrm{O}\right)_{6}(\mathrm{c}, \mathrm{d})$. The neutral structure lies by more than $10 \mathrm{~kJ} \cdot \mathrm{mol}^{-1}$ higher in energy than the dissociated one which is in accord with the previous result for $\mathrm{HNO}_{3}\left(\mathrm{H}_{2} \mathrm{O}\right)_{5 .}{ }^{4}$ 


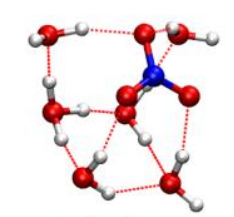

a $\mathbf{0 . 0}$

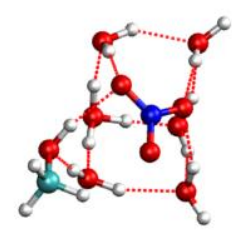

c 0.0
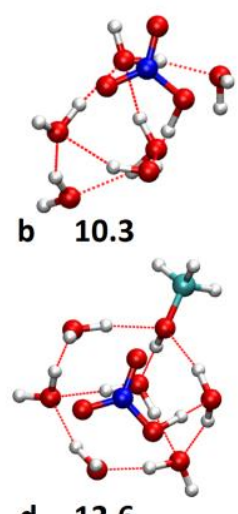

d 12.6

Figure S6: The lowest energy dissociated and the lowest energy neutral structure of $\mathrm{HNO}_{3}\left(\mathrm{H}_{2} \mathrm{O}\right)_{6}(\mathrm{a}, \mathrm{b})$ and $\mathrm{CH}_{3} \mathrm{OH} \cdot \mathrm{HNO}_{3}\left(\mathrm{H}_{2} \mathrm{O}\right)_{6}(\mathrm{c}, \mathrm{d})$. The energy differences are given in $\mathrm{kJ} \cdot \mathrm{mol}^{-1}$.

All studied alcohols can form hydrogen bonds with water and $\mathrm{NO}_{3}{ }^{-}$at the same time (the upper part of Figure S7) or just with two water molecules (the lower part of Figure S7). Based on the analysis of number of hydrogen bonds in the MD trajectories, 2-methyl-3-buten2-ol (c, d) prefers to be surrounded just by water molecules than to interact with both $\mathrm{NO}_{3}{ }^{-}$and $\mathrm{H}_{2} \mathrm{O}$. The average number of its hydrogen bonds with water is 1.6 , while with $\mathrm{NO}_{3}{ }^{-}$it is 0.4 . This picture is further supported by the energy difference between the lowest energy structures from each topological group. Note that number of hydrogen bonds is integer for each instantaneous configuration, but the average along the trajectory is not. 3-methyl-3-buten-1-ol $(e, f)$ prefers to interact with $\mathrm{NO}_{3}{ }^{-}$and $\mathrm{H}_{2} \mathrm{O}$ at the same time. The average number of hydrogen bonds with nitrate is 0.85 and with water 1.1 . The energy difference between the structures (e) and (f) agrees with this observation. Methanol, unlike the bulkier alcohols, sometimes donates one and accepts even two hydrogen bonds, the average number of its hydrogen bonds with nitrate was 1.1 and with water 1.6. The number of hydrogen bonds to $\mathrm{HNO}_{3} / \mathrm{NO}_{3}{ }^{-}$higher than 1.0 is because of the occurrence of neutral acid which can both donate and accept hydrogen bond to methanol. 


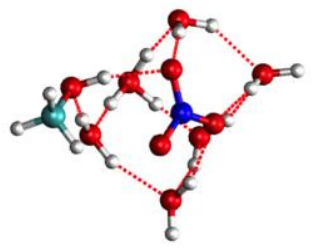

a $\mathbf{0 . 0}$

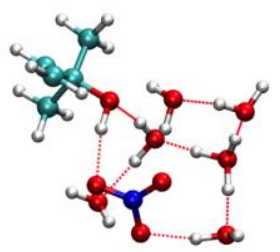

c $\quad 6.4$

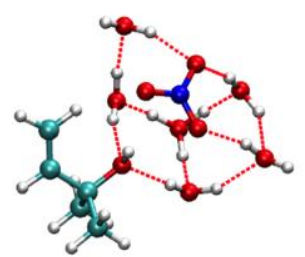

d $\mathbf{0 . 0}$

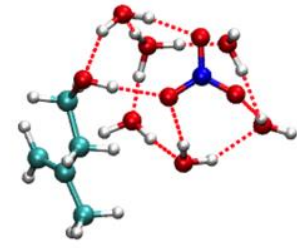

e 0.0

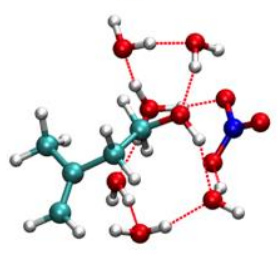

f 6.2

Figure S7: The structures of $X \cdot \mathrm{HNO}_{3}\left(\mathrm{H}_{2} \mathrm{O}\right)_{6}$ clusters, where $\mathrm{X}$ stands for methanol $(\mathrm{a}, \mathrm{b})$, 2-methyl-3buten-2-ol (c, d) and 3-methyl-3-buten-1-ol (e, f). The energy differences between the lowest energy structures where the alcohol forms one hydrogen bonds with $\mathrm{NO}_{3}{ }^{-}$and one with $\mathrm{H}_{2} \mathrm{O}$ (upper part) and those where the alcohol forms two hydrogen bonds with water (lower part) are given in $\mathrm{kJ} \cdot \mathrm{mol}^{-1}$.

Finally, verbenone can act only as a hydrogen bond acceptor, so it does not interact with $\mathrm{NO}_{3}{ }^{-}$at all. The average number of hydrogen bonds with water molecules was 1.4, the representative structures with one and two hydrogen bonds are shown in Figure S8.

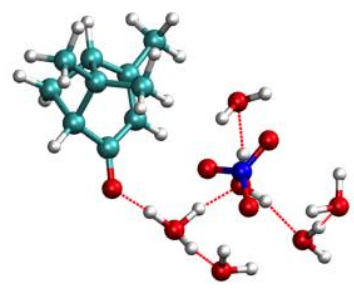

a $\quad 0.0$

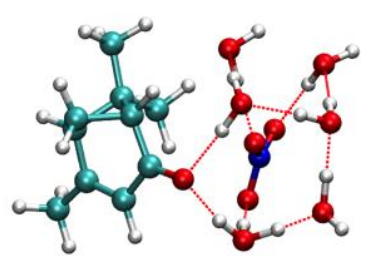

b 3.0

Figure S8: Structures of verbenone. $\mathrm{HNO}_{3}\left(\mathrm{H}_{2} \mathrm{O}\right)_{6}$ clusters, where verbenone forms one hydrogen bond with water (left) and two hydrogen bonds with water (right). The energy difference is given in $\mathrm{kJ}^{\mathrm{J}} \mathrm{mol}^{-1}$. 


\section{REFERENCES}

1. Pysanenko, A.; Lengyel, J.; Fárník, M. Uptake of Methanol on Mixed $\mathrm{HNO}_{3} / \mathrm{H}_{2} \mathrm{O}$ Clusters: An Absolute Pickup Cross Section. J Chem Phys 2018, 148, 154301.

2. Kay, B. D.; Hermann, V.; Castleman, A. W. Studies of Gas-Phase Clusters: The Solvation of $\mathrm{HNO}_{3}$ in Microscopic Aqueous Clusters. Chem Phys Lett 1981, 80, 469-474.

3. Lengyel, J.; Pysanenko, A.; Kočišek, J.; Poterya, V.; Pradzynski, C. C.; Zeuch, T.; Slavíček, P.; Fárník, M. Nucleation of Mixed Nitric Acid-Water Ice Nanoparticles in Molecular Beams that Starts with a $\mathrm{HNO}_{3}$ Molecule. J Phys Chem Lett 2012, 3, 3096-3101.

4. Lengyel, J.; Ončák, M.; Fedor, J.; Kočišek, J.; Pysanenko, A.; Beyer, M. K.; Fárník, M. Electron-Triggered Chemistry in $\mathrm{HNO}_{3} / \mathrm{H}_{2} \mathrm{O}$ Complexes. Phys Chem Chem Phys 2017, 19, 11753-11758.

5. Fedor, J.; Poterya, V.; Pysanenko, A.; Fárník, M. Cluster Cross Sections from Pickup Measurements: Are the Established Methods Consistent? J Chem Phys 2011, 135, 104305.

6. Lengyel, J.; Kočišek, J.; Poterya, V.; Pysanenko, A.; Svrčková, P.; Fárník, M.; Zaouris, D. K.; Fedor, J. Uptake of Atmospheric Molecules by Ice Nanoparticles: Pickup Cross Sections. J Chem Phys 2012, 137, 034304.

7. Lengyel, J.; Pysanenko, A.; Poterya, V.; Slavíček, P.; Fárník, M.; Kočišek, J.; Fedor, J. Irregular Shapes of Water Clusters Generated in Supersonic Expansions. Phys Rev Lett 2014, 112, 113401.

8. Pysanenko, A.; Habartová, A.; Svrčková, P.; Lengyel, J.; Poterya, V.; Roeselová, M.; Fedor, J.; Fárník, M. Lack of Aggregation of Molecules on Ice Nanoparticles. J Phys Chem A 2015, 119, 8991-8999.

9. Zhang, Y. K.; Yang, W. T. Comment on "Generalized Gradient Approximation Made Simple". Phys Rev Lett 1998, 80, 890-890.

10. Grimme, S.; Antony, J.; Ehrlich, S.; Krieg, H. A Consistent and Accurate Ab Initio Parametrization of Density Functional Dispersion Correction (DFT-D) for the 94 Elements H-Pu. J Chem Phys 2010, 132, 154104.

11. Goedecker, S.; Teter, M.; Hutter, J. Separable Dual-Space Gaussian Pseudopotentials. Phys Rev B 1996, 54, 1703-1710.

12. VandeVondele, J.; Hutter, J. Gaussian Basis Sets for Accurate Calculations on Molecular Systems in Gas and Condensed Phases. J Chem Phys 2007, 127, 114105.

13. Bussi, G.; Donadio, D.; Parrinello, M. Canonical Sampling through Velocity Rescaling. J Chem Phys 2007, 126, 014101.

14. Zhao, Y.; Truhlar, D. G. The M06 Suite of Density Functionals for Main Group Thermochemistry, Thermochemical Kinetics, Noncovalent Interactions, Excited States, 
and Transition Elements: Two New Functionals and Systematic Testing of Four M06-Class Functionals and 12 Other Functionals. Theor Chem Acc 2008, 120, 215-241.

15. Boys, S. F.; Bernardi, F. Calculation of Small Molecular Interactions by Differences of Separate Total Energies. Some Procedures with Reduced Errors. Mol Phys 1970, 19, $553-$ 566.

16. Simon, S.; Duran, M.; Dannenberg, J. J. How does Basis Set Superposition Error Change the Potential Surfaces for Hydrogen Bonded Dimers? J Chem Phys 1996, 105, 1102411031.

17. Frisch, M. J.; Trucks, G. W.; Schlegel, H. B.; Scuseria, G. E.; Robb, M. A.; Cheeseman, J. R.; Scalmani, G.; Barone, V.; Petersson, G. A.; Nakatsuji, H.; Li, X.; Caricato, M.; Marenich, A. V.; Bloino, J.; Janesko, B. G.; Gomperts, R.; Mennucci, B.; Hratchian, H. P.; Ortiz, J. V.; Izmaylov, A. F.; Sonnenberg, J. L.; Williams-Young, D.; Ding, F.; Lipparini, F.; Egidi, F.; Goings, J.; Peng, B.; Petrone, A.; Henderson, T.; Ranasinghe, D.; Zakrzewski, V. G.; Gao, J.; Rega, N.; Zheng, G.; Liang, W.; Hada, M.; Ehara, M.; Toyota, K.; Fukuda, R.; Hasegawa, J.; Ishida, M.; Nakajima, T.; Honda, Y.; Kitao, O.; Nakai, H.; Vreven, T.; Throssell, K.; Montgomery, J. A., Jr.;; Peralta, J. E.; Ogliaro, F.; Bearpark, M. J.; Heyd, J. J.; Brothers, E. N.; Kudin, K. N.; Staroverov, V. N.; Keith, T. A.; Kobayashi, R.; Normand, J.; Raghavachari, K.; Rendell, A. P.; Burant, J. C.; Iyengar, S. S.; Tomasi, J.; Cossi, M.; Millam, J. M.; Klene, M.; Adamo, C.; Cammi, R.; Ochterski, J. W.; Martin, R. L.; Morokuma, K.; Farkas, O.; Foresman, J. B.; Fox, D. J. Gaussian 09, Revision D.01, Gaussian 09, Revision D.01: Wallingford CT, 2009.

18. VandeVondele, J.; Krack, M.; Mohamed, F.; Parrinello, M.; Chassaing, T.; Hutter, J. QUICKSTEP: Fast and Accurate Density Functional Calculations Using a Mixed Gaussian and Plane Waves Approach. Comput Phys Commun 2005, 167, 103-128.

19. The CP2K Developers Group. CP2K is freely available at http://www.cp2k.org/.

20. Lewerenz, M.; Schilling, B.; Toennies, J. P. Successive Capture and Coagulation of Atoms and Molecules to Small Clusters in Large Liquid-Helium Clusters. J Chem Phys 1995, 102, 8191-8207.

21. Macler, M.; Bae, Y. K. Comment on: 'Successive Capture and Coagulation of Atoms and Molecules to Small Clusters in Large Liquid-Helium Clusters'. J Chem Phys 1997, 106, 5785-5786.

22. Macler, M.; Bae, Y. K. Determination of Mean Cluster Sizes by Water Capture. J Phys Chem A 1997, 101, 145-148.

23. Pauly, H. Atom, Molecule, and Cluster Beams I: Basic Theory, Production and Detection of Thermal Energy Beams. Vol. 1; Springer-Verlag: Berlin, Heidelberg, 2000.

24. IUPAC in IUPAC Subcommittee for Gas Kinetic Data Evaluation, 2009, Available at http://iupac.poleether.fr/htdocs/supp_info/NewHetIntroOct2009.pdf 
25. Finlayson-Pitts, B. J.; Pitts, J. N. Chemistry of the Upper and Lower Atmosphere: Theory, Experiments, and Applications. Academic Press: San Diego, 2000; 969.

26. Huthwelker, T.; Ammann, M.; Peter, T. The Uptake of Acidic Gases on Ice. Chem Rev 2006, 106, 1375-1444.

27. Davidovits, P.; Kolb, C. E.; Williams, L. R.; Jayne, J. T.; Worsnop, D. R. Mass Accommodation and Chemical Reactions at Gas-Liquid Interfaces. Chem Rev 2006, 106, 1323-1354.

28. Kolb, C. E.; Cox, R. A.; Abbatt, J. P. D.; Ammann, M.; Davis, E. J.; Donaldson, D. J.; Garrett, B. C.; George, C.; Griffiths, P. T.; Hanson, D. R.; Kulmala, M.; McFiggans, G.; Poschl, U.; Riipinen, I.; Rossi, M. J.; Rudich, Y.; Wagner, P. E.; Winkler, P. M.; Worsnop, D. R.; O'Dowd, C. D. An Overview of Current Issues in the Uptake of Atmospheric Trace Gases by Aerosols and Clouds. Atmos Chem Phys 2010, 10, 10561-10605.

29. Nathanson, G. M.; Davidovits, P.; Worsnop, D. R.; Kolb, C. E. Dynamics and Kinetics at the Gas-Liquid Interface. J Phys Chem 1996, 100, 13007-13020.

30. Morris, J. R.; Behr, P.; Antman, M. D.; Ringeisen, B. R.; Splan, J.; Nathanson, G. M. Molecular Beam Scattering from Supercooled Sulfuric Acid: Collisions of $\mathrm{HCl}, \mathrm{HBr}$, and $\mathrm{HNO}_{3}$ with 70 wt \% D $\mathrm{SO}_{4}$. J Phys Chem A 2000, 104, 6738-6751.

31. Thomson, E. S.; Kong, X.; Markovic, N.; Papagiannakopoulos, P.; Pettersson, J. B. C. Collision Dynamics and Uptake of Water on Alcohol-Covered Ice. Atmos Chem Phys 2013, 13, 2223-2233.

32. Johansson, S. M.; Lovric, J.; Kong, X. R.; Thomson, E. S.; Papagiannakopoulos, P.; Briquez, S.; Toubin, C.; Pettersson, J. B. C. Understanding Water Interactions with Organic Surfaces: Environmental Molecular Beam and Molecular Dynamics Studies of the WaterButanol System. Phys Chem Chem Phys 2019, 21, 1141-1151.

33. Kulmala, M.; Kontkanen, J.; Junninen, H.; Lehtipalo, K.; Manninen, H. E.; Nieminen, T.; Petäjä, T.; Sipilä, M.; Schobesberger, S.; Rantala, P.; Franchin, A.; Jokinen, T.; Jarvinen, E.; Äijälä, M.; Kangasluoma, J.; Hakala, J.; Aalto, P. P.; Paasonen, P.; Mikkilä, J.; Vanhanen, J.; Aalto, J.; Hakola, H.; Makkonen, U.; Ruuskanen, T.; Mauldin, R. L.; Duplissy, J.; Vehkamäki, H.; Bäck, J.; Kortelainen, A.; Riipinen, I.; Kurtén, T.; Johnston, M. V.; Smith, J. N.; Ehn, M.; Mentel, T. F.; Lehtinen, K. E. J.; Laaksonen, A.; Kerminen, V. M.; Worsnop, D. R. Direct Observations of Atmospheric Aerosol Nucleation. Science 2013, 339, 943946. 
Cartesian coordinates of systems investigated by theoretical calculations

Names of the structures correspond to their lables in the Figures

$\mathrm{HNO}_{3}\left(\mathrm{H}_{2} \mathrm{O}\right)_{6} \quad$ Figure $3 \mathrm{a}$ is the same as Figure S6a

$\begin{array}{llll}\mathrm{O} & 5.925293 & 4.792317 & 5.331563 \\ \mathrm{O} & 7.002176 & 5.104968 & 7.633881 \\ \mathrm{O} & 8.847732 & 6.748369 & 7.548128 \\ \mathrm{O} & 5.476338 & 6.641495 & 8.999075 \\ \mathrm{O} & 9.398467 & 7.703213 & 5.096552 \\ \mathrm{O} & 7.348007 & 8.725555 & 8.940922 \\ \mathrm{O} & 6.845635 & 8.914877 & 6.299030 \\ \mathrm{~N} & 6.222127 & 7.939503 & 5.846745 \\ \mathrm{O} & 5.192401 & 7.519278 & 6.392453 \\ \mathrm{O} & 6.652904 & 7.364130 & 4.815772 \\ \mathrm{H} & 4.969157 & 4.681133 & 5.369778 \\ \mathrm{H} & 9.121970 & 7.115322 & 6.670900 \\ \mathrm{H} & 8.553316 & 7.503535 & 8.085907 \\ \mathrm{H} & 6.061100 & 5.690636 & 4.957194 \\ \mathrm{H} & 5.085922 & 7.112067 & 8.240830 \\ \mathrm{H} & 6.071673 & 7.310395 & 9.377454 \\ \mathrm{H} & 6.564608 & 4.936959 & 6.726584 \\ \mathrm{H} & 6.348317 & 5.626004 & 8.220492 \\ \mathrm{H} & 7.831763 & 5.755372 & 7.533077 \\ \mathrm{H} & 7.019261 & 8.996554 & 8.056287 \\ \mathrm{H} & 7.555811 & 9.533045 & 9.419864 \\ \mathrm{H} & 8.470065 & 7.718357 & 4.794955 \\ \mathrm{H} & 9.681428 & 8.622434 & 5.063769\end{array}$

$\mathrm{CH}_{3} \mathrm{OH} \cdot \mathrm{HNO}_{3}\left(\mathrm{H}_{2} \mathrm{O}\right)_{6}$ Figure $3 \mathrm{~b}$ is the same as Figure S6c and as Figure S7a

$\begin{array}{llll}\mathrm{O} & 5.533188 & 7.914036 & 7.551719 \\ \mathrm{O} & 5.405156 & 5.110457 & 6.297534 \\ \mathrm{~N} & 6.610112 & 5.296749 & 6.169043 \\ \mathrm{O} & 7.049107 & 5.815935 & 5.105160 \\ \mathrm{O} & 7.409655 & 4.999559 & 7.083359 \\ \mathrm{O} & 7.778605 & 8.856041 & 7.100053 \\ \mathrm{O} & 7.643947 & 9.053705 & 4.552352 \\ \mathrm{O} & 5.626773 & 5.777794 & 9.149746 \\ \mathrm{O} & 9.418716 & 6.913637 & 7.155363 \\ \mathrm{O} & 5.156371 & 7.724066 & 4.693923 \\ \mathrm{O} & 9.418040 & 6.832759 & 4.335776 \\ \mathrm{H} & 5.491232 & 7.116791 & 8.140920 \\ \mathrm{H} & 9.811904 & 6.912654 & 6.267798 \\ \mathrm{H} & 8.842083 & 6.122674 & 7.162219 \\ \mathrm{H} & 5.137560 & 7.687031 & 6.694505 \\ \mathrm{H} & 6.757481 & 8.694812 & 4.367870 \\ \mathrm{H} & 8.275145 & 8.383082 & 4.237563 \\ \mathrm{H} & 6.828840 & 8.466053 & 7.349464 \\ \mathrm{H} & 7.744421 & 9.038858 & 6.096577 \\ \mathrm{H} & 8.465883 & 8.099997 & 7.202654 \\ \mathrm{H} & 4.325739 & 7.660629 & 4.213442 \\ \mathrm{H} & 5.575223 & 6.842370 & 4.647706 \\ \mathrm{H} & 9.907126 & 6.399915 & 3.630072 \\ \mathrm{H} & 8.668358 & 6.245420 & 4.566361\end{array}$




$\begin{array}{llll}\mathrm{H} & 6.203133 & 5.221173 & 8.600352 \\ \mathrm{C} & 4.395946 & 5.095699 & 9.363410 \\ \mathrm{H} & 4.553041 & 4.183810 & 9.953999 \\ \mathrm{H} & 3.746424 & 5.772829 & 9.927064 \\ \mathrm{H} & 3.918757 & 4.836187 & 8.409325\end{array}$

Isoprene. $\mathrm{HNO}_{3}\left(\mathrm{H}_{2} \mathrm{O}\right)_{6}$ Figure $3 \mathrm{c}$

$\begin{array}{cccc}\mathrm{C} & 7.886272 & 11.103456 & 10.668805 \\ \mathrm{C} & 8.557158 & 9.914819 & 11.301464 \\ \mathrm{C} & 8.448433 & 8.610138 & 10.628076 \\ \mathrm{C} & 7.803367 & 8.397934 & 9.474441 \\ \mathrm{C} & 9.261323 & 10.014600 & 12.443141 \\ \mathrm{O} & 12.438728 & 6.992556 & 6.127222 \\ \mathrm{O} & 12.682458 & 6.840530 & 8.805960 \\ \mathrm{~N} & 12.477023 & 7.910710 & 9.407653 \\ \mathrm{O} & 11.685712 & 7.946507 & 10.364166 \\ \mathrm{O} & 13.060719 & 8.959777 & 9.050463 \\ \mathrm{O} & 11.127673 & 10.785571 & 9.823802 \\ \mathrm{O} & 10.259824 & 9.919917 & 7.623350 \\ \mathrm{O} & 9.917798 & 7.455165 & 7.385485 \\ \mathrm{O} & 12.520476 & 9.768854 & 6.419409 \\ \mathrm{O} & 9.914458 & 5.931765 & 9.654231 \\ \mathrm{H} & 13.036302 & 9.567151 & 7.220325 \\ \mathrm{H} & 10.661844 & 7.126926 & 6.852699 \\ \mathrm{H} & 9.866126 & 6.875033 & 8.179549 \\ \mathrm{H} & 12.529855 & 8.920240 & 5.945096 \\ \mathrm{H} & 10.645795 & 10.479629 & 10.608814 \\ \mathrm{H} & 11.953184 & 10.262495 & 9.824819 \\ \mathrm{H} & 11.116417 & 9.965382 & 7.071683 \\ \mathrm{H} & 10.514204 & 10.261962 & 8.568516 \\ \mathrm{H} & 10.036417 & 8.902409 & 7.630662 \\ \mathrm{H} & 10.373827 & 5.097270 & 9.515015 \\ \mathrm{H} & 10.587446 & 6.510669 & 10.065137 \\ \mathrm{H} & 12.845362 & 6.297217 & 5.602421 \\ \mathrm{H} & 12.772751 & 6.889095 & 7.044878 \\ \mathrm{H} & 9.746637 & 9.141071 & 12.877503 \\ \mathrm{H} & 9.355815 & 10.962245 & 12.972126 \\ \mathrm{H} & 8.927884 & 7.767885 & 11.129298 \\ \mathrm{H} & 7.304178 & 9.201296 & 8.933464 \\ \mathrm{H} & 7.756026 & 7.399184 & 9.046335 \\ \mathrm{H} & 8.269822 & 11.270439 & 9.652700 \\ \mathrm{H} & 8.057240 & 12.009144 & 11.258914 \\ \mathrm{H} & 6.805027 & 10.932926 & 10.585075\end{array}$

2-methyl-3-buten-2-ol. $\mathrm{HNO}_{3}\left(\mathrm{H}_{2} \mathrm{O}\right)_{6} \quad$ Figure $3 \mathrm{~d}$ is the same as Figure $\mathrm{S} 7 \mathrm{~d}$
C $\quad 10.089769 \quad 10.343566 \quad 6.096798$
C $\quad 10.279817 \quad 9.486257 \quad 7.348111$
C $\quad 11.193133 \quad 8.295047 \quad 7.068164$
C $\quad 10.843956 \quad 10.323256 \quad 8.470799$
C $\quad 10.257591 \quad 10.547893 \quad 9.645475$
$\begin{array}{llll}\text { O } & 9.021083 & 8.910651 & 7.721961\end{array}$
$\begin{array}{llll}\text { H } & 8.372699 & 9.590371 & 7.972937\end{array}$
$\begin{array}{llll}\mathrm{H} & 9.701333 & 9.725481 & 5.278171\end{array}$

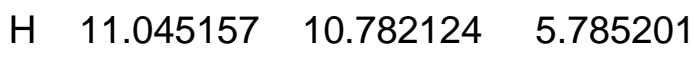




$\begin{array}{cccc}\mathrm{H} & 9.385506 & 11.160315 & 6.298227 \\ \mathrm{H} & 11.819639 & 10.768201 & 8.259395 \\ \mathrm{H} & 9.280777 & 10.135206 & 9.899299 \\ \mathrm{H} & 10.743546 & 11.168670 & 10.395469 \\ \mathrm{H} & 12.191797 & 8.642629 & 6.781267 \\ \mathrm{H} & 10.778878 & 7.693126 & 6.250182 \\ \mathrm{H} & 11.281933 & 7.671515 & 7.965503 \\ \mathrm{O} & 8.049866 & 6.814139 & 6.147072 \\ \mathrm{O} & 8.074923 & 5.403090 & 8.288027 \\ \mathrm{O} & 9.053921 & 7.072518 & 9.834141 \\ \mathrm{O} & 5.558706 & 5.400069 & 8.598376 \\ \mathrm{O} & 7.493059 & 7.793352 & 11.927079 \\ \mathrm{O} & 5.173547 & 6.729188 & 6.147386 \\ \mathrm{O} & 5.646611 & 7.885193 & 9.809817 \\ \mathrm{~N} & 6.275420 & 8.674085 & 9.063534 \\ \mathrm{O} & 6.200222 & 8.551874 & 7.823071 \\ \mathrm{O} & 6.979360 & 9.562235 & 9.552872 \\ \mathrm{H} & 8.206558 & 7.685012 & 6.561107 \\ \mathrm{H} & 8.557097 & 7.325999 & 10.648651 \\ \mathrm{H} & 9.112647 & 7.868357 & 9.273606 \\ \mathrm{H} & 7.116340 & 6.813403 & 5.876647 \\ \mathrm{H} & 5.200358 & 5.545519 & 7.707549 \\ \mathrm{H} & 5.407036 & 6.250747 & 9.060064 \\ \mathrm{H} & 8.132549 & 5.890880 & 7.393100 \\ \mathrm{H} & 7.064105 & 5.322918 & 8.465650 \\ \mathrm{H} & 8.485535 & 6.063356 & 9.004425 \\ \mathrm{H} & 5.283751 & 7.476236 & 6.771313 \\ \mathrm{H} & 4.459117 & 6.964951 & 5.548838 \\ \mathrm{H} & 6.692517 & 7.896749 & 11.379826 \\ \mathrm{H} & 7.692232 & 8.689266 & 12.218163\end{array}$

3-methyl-3-buten-1-ol. $\mathrm{HNO}_{3}\left(\mathrm{H}_{2} \mathrm{O}\right)_{6} \quad$ Figure $3 \mathrm{e}$ is the same as Figure S7e
O 7.186500
6.052925
3.578732
O 7.259840
5.512722
6.101584
O 9.402838
6.545820
6.876852
O 5.094344
6.428169
6.937254
O 9.549490
8.854274
5.561493
O 9.135163
7.996739
2.838232
O 6.829750
9.110421
3.762878
N 6.272656
8.646833
4.768160
O 6.756235
8.864414
5.903801
O 5.248641
7.950458
4.648010
H 6.404136
6.601610
3.415149
H 9.602854
6.694485
7.812910
H 9.531731
7.416399
6.419693
H 7.939794
6.566392
3.236912
H 5.164659
7.039871
7.696894
H 4.909460
7.020578
6.179553
H 7.245078
5.687232
5.103601
H 6.376052
5.895257
6.520122
H 8.116487
5.951578
6.488065
$\begin{array}{ll}H & 8.379087\end{array}$
8.603723
2.934274
$\begin{array}{ll}\mathrm{H} & 9.503757\end{array}$
8.146827
1.962358
H $\quad 9.745657$
8.651546
4.634556 


$\begin{array}{cccc}\mathrm{H} & 8.609548 & 9.113304 & 5.562180 \\ \mathrm{O} & 5.853842 & 8.507743 & 8.587716 \\ \mathrm{C} & 7.075818 & 7.976425 & 9.084468 \\ \mathrm{C} & 8.228997 & 8.949186 & 8.902439 \\ \mathrm{C} & 9.577124 & 8.459718 & 9.367163 \\ \mathrm{C} & 9.749091 & 7.334654 & 10.075482 \\ \mathrm{C} & 10.731083 & 9.328552 & 8.949263 \\ \mathrm{H} & 6.031067 & 8.867085 & 7.702423 \\ \mathrm{H} & 10.743231 & 7.024916 & 10.395360 \\ \mathrm{H} & 8.914932 & 6.703831 & 10.378874 \\ \mathrm{H} & 10.592934 & 10.350399 & 9.328720 \\ \mathrm{H} & 10.768374 & 9.397135 & 7.852531 \\ \mathrm{H} & 11.684799 & 8.939191 & 9.319951 \\ \mathrm{H} & 8.310703 & 9.208122 & 7.835583 \\ \mathrm{H} & 7.993125 & 9.890423 & 9.421088 \\ \mathrm{H} & 7.312112 & 7.023576 & 8.579112 \\ \mathrm{H} & 6.904490 & 7.761284 & 10.145497\end{array}$

Pinene. $\mathrm{HNO}_{3}\left(\mathrm{H}_{2} \mathrm{O}\right)_{6} \quad$ Figure $3 \mathrm{f}$

$\begin{array}{cccc}\mathrm{O} & 9.244230 & 10.929138 & 10.453374 \\ \mathrm{O} & 10.063530 & 8.990101 & 11.855245 \\ \mathrm{O} & 9.820136 & 6.719250 & 10.650712 \\ \mathrm{O} & 12.413388 & 9.459802 & 12.455753 \\ \mathrm{O} & 11.004560 & 10.867258 & 8.439419 \\ \mathrm{O} & 13.755470 & 7.145085 & 12.787264 \\ \mathrm{O} & 12.522032 & 7.136665 & 10.292463 \\ \mathrm{~N} & 12.420705 & 8.155943 & 9.568459 \\ \mathrm{O} & 13.117545 & 9.160498 & 9.796352 \\ \mathrm{O} & 11.599197 & 8.155375 & 8.636323 \\ \mathrm{H} & 9.876130 & 10.991636 & 9.691303 \\ \mathrm{H} & 9.314723 & 6.781266 & 9.829178 \\ \mathrm{H} & 10.743609 & 6.561251 & 10.371016 \\ \mathrm{H} & 8.387480 & 10.751264 & 10.044638 \\ \mathrm{H} & 12.853239 & 9.547622 & 11.587595 \\ \mathrm{H} & 12.889542 & 8.701736 & 12.858507 \\ \mathrm{H} & 9.705695 & 9.774292 & 11.288006 \\ \mathrm{H} & 11.072100 & 9.161911 & 12.148010 \\ \mathrm{H} & 9.948648 & 8.100350 & 11.378142 \\ \mathrm{H} & 14.704208 & 7.023559 & 12.880250 \\ \mathrm{H} & 13.552781 & 7.027144 & 11.841128 \\ \mathrm{H} & 11.258352 & 9.925722 & 8.353134 \\ \mathrm{H} & 11.839409 & 11.304672 & 8.639315 \\ \mathrm{C} & 8.519500 & 8.688537 & 8.341309 \\ \mathrm{C} & 8.822932 & 8.803103 & 6.865187 \\ \mathrm{C} & 7.517759 & 8.805774 & 6.058353 \\ \mathrm{C} & 6.491475 & 9.814684 & 6.666424 \\ \mathrm{C} & 6.178879 & 8.669906 & 7.692984 \\ \mathrm{C} & 7.248528 & 8.635971 & 8.765245 \\ \mathrm{C} & 6.609824 & 7.666547 & 6.586702 \\ \mathrm{C} & 5.308113 & 10.071863 & 5.735127 \\ \mathrm{C} & 6.998418 & 11.155311 & 7.183009 \\ \mathrm{C} & 6.825811 & 8.557025 & 10.203006 \\ \mathrm{H} & 7.702961 & 8.866215 & 4.978853 \\ \mathrm{H} & 5.162351 & 8.611853 & 8.101890 \\ \mathrm{H} & 7.106586 & 6.753028 & 6.930832\end{array}$




$\begin{array}{cccc}\mathrm{H} & 5.802490 & 7.410554 & 5.898022 \\ \mathrm{H} & 9.404723 & 9.717522 & 6.676536 \\ \mathrm{H} & 9.462151 & 7.964908 & 6.552234 \\ \mathrm{H} & 5.631630 & 10.674257 & 4.875762 \\ \mathrm{H} & 4.528425 & 10.635473 & 6.265528 \\ \mathrm{H} & 4.854636 & 9.152859 & 5.350659 \\ \mathrm{H} & 7.926417 & 11.074797 & 7.756236 \\ \mathrm{H} & 6.234591 & 11.627971 & 7.816999 \\ \mathrm{H} & 7.190468 & 11.832306 & 6.340076 \\ \mathrm{H} & 9.356562 & 8.684955 & 9.037366 \\ \mathrm{H} & 7.681231 & 8.514999 & 10.886412 \\ \mathrm{H} & 6.205326 & 7.667078 & 10.375488 \\ \mathrm{H} & 6.202607 & 9.423652 & 10.471511\end{array}$

Verbenone $\cdot \mathrm{HNO}_{3}\left(\mathrm{H}_{2} \mathrm{O}\right)_{6} \quad$ Figure $3 \mathrm{~g}$ is the same as Figure S8a

$\begin{array}{cccc}\mathrm{O} & 7.818672 & 11.200550 & 10.576698 \\ \mathrm{O} & 8.603714 & 12.678675 & 8.374400 \\ \mathrm{O} & 11.417735 & 13.013803 & 8.431973 \\ \mathrm{O} & 8.716151 & 11.105840 & 6.382778 \\ \mathrm{O} & 12.756813 & 11.709529 & 10.347161 \\ \mathrm{O} & 11.195461 & 10.877651 & 6.581385 \\ \mathrm{O} & 9.447239 & 9.700296 & 8.869846 \\ \mathrm{~N} & 10.498506 & 9.764454 & 9.540415 \\ \mathrm{O} & 11.602357 & 9.587423 & 8.968071 \\ \mathrm{O} & 10.459846 & 10.012863 & 10.752700 \\ \mathrm{H} & 8.239519 & 10.474442 & 10.075866 \\ \mathrm{H} & 11.930313 & 12.613365 & 9.181383 \\ \mathrm{H} & 11.801748 & 13.883528 & 8.285707 \\ \mathrm{H} & 8.410710 & 11.288363 & 11.332508 \\ \mathrm{H} & 8.256461 & 10.199625 & 6.500108 \\ \mathrm{H} & 9.750181 & 10.948219 & 6.399129 \\ \mathrm{H} & 8.306312 & 12.285429 & 9.221315 \\ \mathrm{H} & 8.565870 & 11.700870 & 7.207294 \\ \mathrm{H} & 9.548484 & 12.886482 & 8.499916 \\ \mathrm{H} & 11.354663 & 10.192815 & 7.264473 \\ \mathrm{H} & 11.440155 & 11.699725 & 7.044489 \\ \mathrm{H} & 12.695843 & 10.839155 & 9.910669 \\ \mathrm{H} & 12.187922 & 11.572609 & 11.114998 \\ \mathrm{C} & 6.294789 & 9.560789 & 8.412396 \\ \mathrm{C} & 5.446826 & 9.119777 & 9.366054 \\ \mathrm{C} & 5.066870 & 7.657469 & 9.336589 \\ \mathrm{C} & 6.355653 & 6.768871 & 9.192111 \\ \mathrm{C} & 6.278415 & 7.161928 & 7.672802 \\ \mathrm{C} & 6.818694 & 8.559040 & 7.477422 \\ \mathrm{C} & 4.739975 & 7.301205 & 7.859441 \\ \mathrm{C} & 7.601842 & 7.121947 & 9.991731 \\ \mathrm{C} & 6.053450 & 5.286063 & 9.399208 \\ \mathrm{C} & 4.883321 & 9.982523 & 10.443767 \\ \mathrm{O} & 7.629440 & 8.813956 & 6.587051 \\ \mathrm{H} & 4.347677 & 7.400517 & 10.123210 \\ \mathrm{H} & 6.688899 & 6.481740 & 6.919846 \\ \mathrm{H} & 4.220872 & 6.348230 & 7.744749 \\ \mathrm{H} & 4.234513 & 8.073865 & 7.272744 \\ \mathrm{H} & 7.442203 & 6.877254 & 11.050156\end{array}$




$\begin{array}{cccc}\mathrm{H} & 8.450044 & 6.523010 & 9.635627 \\ \mathrm{H} & 7.887873 & 8.172976 & 9.917503 \\ \mathrm{H} & 6.917059 & 4.687584 & 9.082220 \\ \mathrm{H} & 5.884397 & 5.090481 & 10.466088 \\ \mathrm{H} & 5.176529 & 4.934329 & 8.847422 \\ \mathrm{H} & 6.624138 & 10.596197 & 8.345439 \\ \mathrm{H} & 5.226316 & 9.605980 & 11.418658 \\ \mathrm{H} & 3.786571 & 9.918040 & 10.441792 \\ \mathrm{H} & 5.204660 & 11.021495 & 10.341771\end{array}$

$\mathrm{HNO}_{3}\left(\mathrm{H}_{2} \mathrm{O}\right)_{6} \quad$ Figure S6b

$\begin{array}{llll}\text { O } & 5.987224 & 8.515550 & 7.744783\end{array}$

$\begin{array}{llll}\text { O } & 3.134598 & 11.620491 & 5.449123\end{array}$

$\begin{array}{llll}\mathrm{O} & 4.949731 & 9.637049 & 5.406207\end{array}$

$\begin{array}{llll}\text { O } & 3.788371 & 10.063837 & 8.668220\end{array}$

$\begin{array}{llll}\text { O } & 7.409378 & 10.681870 & 8.775146\end{array}$

$\begin{array}{llll}\text { O } & 5.406174 & 11.779719 & 7.250761\end{array}$

$\begin{array}{llll}O & 3.324035 & 7.580203 & 7.047430\end{array}$

$\begin{array}{llll}\mathrm{N} & 2.559504 & 8.267752 & 6.400379\end{array}$

$\begin{array}{llll}\mathrm{O} & 2.095122 & 9.380454 & 6.987229\end{array}$

$\begin{array}{llll}O & 2.166373 & 8.059422 & 5.283904\end{array}$

H $\quad 5.794719 \quad 7.573864 \quad 7.802195$

$\begin{array}{llll}H & 4.227579 & 10.299624 & 5.296989\end{array}$

H $\quad 5.001132 \quad 9.154015 \quad 4.575936$

$\begin{array}{llll}H & 5.589275 & 8.799308 & 6.897619\end{array}$

$\begin{array}{llll}\mathrm{H} & 2.771176 & 9.608520 & 7.766877\end{array}$

$\begin{array}{llll}\mathrm{H} & 4.443387 & 9.345219 & 8.699094\end{array}$

$\begin{array}{llll}\mathrm{H} & 3.519367 & 12.168653 & 6.146927\end{array}$

$\begin{array}{llll}H & 4.295477 & 10.788777 & 8.238927\end{array}$

$\begin{array}{llll}\mathrm{H} & 2.365386 & 11.187870 & 5.844333\end{array}$

$\begin{array}{llll}\mathrm{H} & 6.193807 & 11.735259 & 7.823475\end{array}$

H $\quad 5.642769 \quad 11.216615 \quad 6.498604$

$\begin{array}{llll}H & 7.143977 & 9.785242 & 8.508300\end{array}$

H $\quad 8.362152 \quad 10.663529 \quad 8.895056$

$\mathrm{CH}_{3} \mathrm{OH} \cdot \mathrm{HNO}_{3}\left(\mathrm{H}_{2} \mathrm{O}\right)_{6}$ Figure S6d

$\begin{array}{llll}\mathrm{O} & 4.304525 & 7.411557 & 4.731195 \\ \mathrm{O} & 3.698783 & 6.759450 & 7.221357 \\ \mathrm{O} & 8.009022 & 7.827241 & 6.048284 \\ \mathrm{O} & 7.468569 & 7.503308 & 8.795620 \\ \mathrm{O} & 7.540272 & 5.019219 & 7.356116 \\ \mathrm{~N} & 6.351299 & 4.833152 & 7.518629 \\ \mathrm{O} & 5.765621 & 4.878805 & 8.581073 \\ \mathrm{O} & 5.611323 & 4.571540 & 6.451090 \\ \mathrm{O} & 5.874018 & 9.390640 & 5.996398 \\ \mathrm{O} & 5.110876 & 8.698385 & 8.623389 \\ \mathrm{O} & 6.616810 & 5.912080 & 4.664334 \\ \mathrm{H} & 3.993073 & 7.109156 & 5.625409 \\ \mathrm{H} & 7.800058 & 7.477226 & 7.877613 \\ \mathrm{H} & 7.441176 & 6.577437 & 9.068154 \\ \mathrm{H} & 7.265492 & 6.505398 & 5.106679 \\ \mathrm{H} & 7.281045 & 8.498779 & 5.998233 \\ \mathrm{H} & 3.535090 & 7.421551 & 4.155093 \\ \mathrm{H} & 4.001405 & 5.890169 & 7.515019 \\ \mathrm{H} & 4.094811 & 7.399572 & 7.841848\end{array}$




$\begin{array}{cccc}\mathrm{H} & 5.236640 & 8.909149 & 5.442990 \\ \mathrm{H} & 5.505056 & 9.357959 & 6.896172 \\ \mathrm{H} & 4.871024 & 9.194536 & 9.410613 \\ \mathrm{H} & 5.985663 & 8.267455 & 8.806424 \\ \mathrm{H} & 6.115792 & 5.056459 & 5.626677 \\ \mathrm{H} & 5.849846 & 6.482446 & 4.453777 \\ \mathrm{C} & 9.246768 & 8.422171 & 5.671984 \\ \mathrm{H} & 9.504289 & 9.248628 & 6.346904 \\ \mathrm{H} & 10.019294 & 7.650622 & 5.743752 \\ \mathrm{H} & 9.208473 & 8.795596 & 4.640347\end{array}$

$\mathrm{CH}_{3} \mathrm{OH} \cdot \mathrm{HNO}_{3}\left(\mathrm{H}_{2} \mathrm{O}\right)_{6}$ Figure S7b

$\begin{array}{cccc}\mathrm{O} & 5.320337 & 7.930674 & 7.125790 \\ \mathrm{O} & 5.216791 & 5.279375 & 5.883457 \\ \mathrm{~N} & 6.406488 & 5.126076 & 5.606885 \\ \mathrm{O} & 6.851938 & 5.537720 & 4.495442 \\ \mathrm{O} & 7.196070 & 4.595222 & 6.409408 \\ \mathrm{O} & 7.603609 & 8.974035 & 7.128684 \\ \mathrm{O} & 8.067220 & 8.819421 & 4.646296 \\ \mathrm{O} & 6.236676 & 5.740328 & 8.664677 \\ \mathrm{O} & 8.731520 & 6.841574 & 7.858095 \\ \mathrm{O} & 5.468211 & 7.845244 & 4.243005 \\ \mathrm{O} & 9.340607 & 6.361694 & 5.118127 \\ \mathrm{H} & 5.424121 & 7.077520 & 7.590123 \\ \mathrm{H} & 8.966478 & 6.397741 & 7.022416 \\ \mathrm{H} & 8.023005 & 6.311968 & 8.265043 \\ \mathrm{H} & 5.100229 & 7.717609 & 6.202040 \\ \mathrm{H} & 7.197594 & 8.572286 & 4.280175 \\ \mathrm{H} & 8.618338 & 8.016668 & 4.591545 \\ \mathrm{H} & 6.622965 & 8.631797 & 7.159168 \\ \mathrm{H} & 7.829075 & 9.016532 & 6.123472 \\ \mathrm{H} & 8.137060 & 8.161860 & 7.484351 \\ \mathrm{H} & 5.743624 & 6.907922 & 4.152325 \\ \mathrm{H} & 4.733474 & 7.977203 & 3.636972 \\ \mathrm{H} & 10.127783 & 5.907289 & 4.804469 \\ \mathrm{H} & 8.569617 & 5.825307 & 4.828339 \\ \mathrm{H} & 6.318238 & 5.043853 & 7.986221 \\ \mathrm{C} & 5.489188 & 5.258663 & 9.775903 \\ \mathrm{H} & 6.000875 & 4.417906 & 10.261138 \\ \mathrm{H} & 5.400618 & 6.081483 & 10.491456 \\ \mathrm{H} & 4.484513 & 4.944572 & 9.464828\end{array}$

2-methyl-3-buten-2-ol. $\mathrm{HNO}_{3}\left(\mathrm{H}_{2} \mathrm{O}\right)_{6}$ Figure S7c

$\begin{array}{cccc}\text { C } & 9.048512 & 10.052959 & 5.722705 \\ \text { C } & 9.859896 & 9.805507 & 6.997922 \\ \text { C } & 11.047539 & 8.889534 & 6.720198 \\ \text { C } & 10.334590 & 11.122749 & 7.564228 \\ \text { C } & 10.028653 & 11.603340 & 8.767492 \\ \text { O } & 9.041061 & 9.114094 & 7.948250 \\ \text { H } & 8.194281 & 9.600913 & 8.052778 \\ \text { H } & 8.727846 & 9.095339 & 5.292116 \\ \text { H } & 9.656048 & 10.582167 & 4.979413 \\ \text { H } & 8.170442 & 10.670611 & 5.953015 \\ \text { H } & 10.974721 & 11.704244 & 6.895280\end{array}$




$\begin{array}{cccc}\mathrm{H} & 9.395209 & 11.057301 & 9.465705 \\ \mathrm{H} & 10.408276 & 12.569764 & 9.092731 \\ \mathrm{H} & 11.734309 & 9.363484 & 6.009676 \\ \mathrm{H} & 10.697219 & 7.941492 & 6.293203 \\ \mathrm{H} & 11.590472 & 8.687584 & 7.650482 \\ \mathrm{O} & 7.675658 & 6.944680 & 6.903031 \\ \mathrm{O} & 6.798631 & 5.458937 & 8.687722 \\ \mathrm{O} & 8.242962 & 5.879461 & 10.738354 \\ \mathrm{O} & 4.431381 & 6.174364 & 9.316874 \\ \mathrm{O} & 8.892507 & 8.443396 & 10.672241 \\ \mathrm{O} & 5.883102 & 8.394528 & 5.433463 \\ \mathrm{O} & 4.783539 & 8.543424 & 8.025443 \\ \mathrm{~N} & 5.857025 & 8.990535 & 8.498560 \\ \mathrm{O} & 6.441585 & 9.917570 & 7.912099 \\ \mathrm{O} & 6.326891 & 8.488322 & 9.531025 \\ \mathrm{H} & 8.236101 & 7.657543 & 7.272876 \\ \mathrm{H} & 8.967581 & 5.306104 & 11.002195 \\ \mathrm{H} & 8.574866 & 6.816796 & 10.771193 \\ \mathrm{H} & 7.039839 & 7.391884 & 6.297373 \\ \mathrm{H} & 4.375298 & 6.350159 & 10.262803 \\ \mathrm{H} & 4.414938 & 7.067089 & 8.901610 \\ \mathrm{H} & 7.137776 & 6.091693 & 7.918122 \\ \mathrm{H} & 5.844861 & 5.718804 & 8.954395 \\ \mathrm{H} & 7.399902 & 5.590792 & 9.498675 \\ \mathrm{H} & 6.272650 & 9.273003 & 5.354676 \\ \mathrm{H} & 5.236190 & 8.510346 & 6.151922 \\ \mathrm{H} & 7.986181 & 8.736390 & 10.475605 \\ \mathrm{H} & 9.347284 & 8.634421 & 9.836097\end{array}$

3-methyl-3-buten-1-ol. $\mathrm{HNO}_{3}\left(\mathrm{H}_{2} \mathrm{O}\right)_{6}$ Figure S7f
O 7.207384
5.375345
5.578011
O 6.268050
5.383121
7.941592
O 9.557496
6.310650
5.445262
O 4.629406
7.361731
7.477769
O 10.247708
8.871533
5.419587
O 7.946874
10.482156
5.378619
O 7.143823
8.101226
4.450750
N 5.911991
8.014281
4.642122
O 5.204398
8.997724
4.768629
O 5.402909
6.848953
4.722345
H 6.481562
5.975733
5.113473
H $\quad 10.093676$
5.892116
4.764886
H $\quad 9.729971$
7.285641
5.365707
H 8.131221
5.809869
5.499344
H $\quad 5.177084$
8.175063
7.502390
H 4.362427
7.286724
6.550189
H $\quad 6.913360$
5.299354
6.551745
H 5.582861
6.110599
7.840430
H 5.809333
4.609060
8.281005
H $\quad 7.726877$
11.294202
4.912651
H $\quad 7.542140$
9.749054
4.860752
H 9.563985
9.564791
5.381657
H 10.653809
8.957008
6.294338
O 6.587622
9.244112
7.559875 


$\begin{array}{cccc}\text { C } & 7.751125 & 8.444696 & 7.736087 \\ \mathrm{C} & 8.821769 & 9.208120 & 8.513413 \\ \mathrm{C} & 10.122360 & 8.454455 & 8.656096 \\ \mathrm{C} & 11.304305 & 9.068651 & 8.511702 \\ \mathrm{C} & 10.018787 & 6.991102 & 8.989108 \\ \mathrm{H} & 6.785934 & 9.901707 & 6.874978 \\ \mathrm{H} & 12.242194 & 8.531864 & 8.648987 \\ \mathrm{H} & 11.363716 & 10.133836 & 8.283423 \\ \mathrm{H} & 9.570535 & 6.437221 & 8.152342 \\ \mathrm{H} & 9.369745 & 6.840498 & 9.863038 \\ \mathrm{H} & 11.004287 & 6.562985 & 9.198337 \\ \mathrm{H} & 8.998063 & 10.172798 & 8.019006 \\ \mathrm{H} & 8.417025 & 9.423023 & 9.513835 \\ \mathrm{H} & 8.137615 & 8.118549 & 6.759429 \\ \mathrm{H} & 7.431602 & 7.554094 & 8.288358\end{array}$

Verbenone. $\mathrm{HNO}_{3}\left(\mathrm{H}_{2} \mathrm{O}\right)_{6} \quad$ Figure $\mathrm{S} 8 \mathrm{~b}$

\begin{tabular}{cccc}
$\mathrm{O}$ & 10.477622 & 6.626950 & 6.664172 \\
$\mathrm{O}$ & 8.484085 & 5.340140 & 8.321424 \\
$\mathrm{O}$ & 9.350856 & 6.229783 & 10.775648 \\
$\mathrm{O}$ & 6.211367 & 6.477847 & 8.176263 \\
$\mathrm{O}$ & 11.269612 & 7.631979 & 9.253800 \\
$\mathrm{O}$ & 6.048611 & 8.712548 & 9.178862 \\
$\mathrm{O}$ & 9.284345 & 9.185454 & 6.441794 \\
$\mathrm{~N}$ & 8.502114 & 9.098371 & 7.386689 \\
$\mathrm{O}$ & 7.474190 & 9.829216 & 7.426777 \\
$\mathrm{O}$ & 8.707897 & 8.299938 & 8.322637 \\
$\mathrm{H}$ & 10.137283 & 7.526610 & 6.493059 \\
$\mathrm{H}$ & 10.179761 & 6.608445 & 10.433638 \\
$\mathrm{H}$ & 8.793457 & 7.005626 & 10.948941 \\
$\mathrm{H}$ & 10.719726 & 6.269371 & 5.805196 \\
$\mathrm{H}$ & 5.546686 & 5.797759 & 8.315076 \\
$\mathrm{H}$ & 6.074584 & 7.717257 & 8.792812 \\
$\mathrm{H}$ & 9.129328 & 5.758905 & 7.724313 \\
$\mathrm{H}$ & 7.130657 & 6.029552 & 8.214765 \\
$\mathrm{H}$ & 8.800443 & 5.561237 & 9.225785 \\
$\mathrm{H}$ & 6.598013 & 9.247581 & 8.475391 \\
$\mathrm{H}$ & 6.626356 & 8.708001 & 9.992255 \\
$\mathrm{H}$ & 11.603552 & 7.073649 & 8.539394 \\
$\mathrm{H}$ & 10.435504 & 7.962390 & 8.871844 \\
$\mathrm{C}$ & 7.934532 & 11.083082 & 11.057942 \\
$\mathrm{C}$ & 8.761839 & 12.134494 & 11.245774 \\
$\mathrm{C}$ & 10.201744 & 11.836097 & 11.588852 \\
$\mathrm{C}$ & 10.764021 & 10.771602 & 10.579851 \\
$\mathrm{C}$ & 10.001757 & 9.727408 & 11.479667 \\
$\mathrm{C}$ & 8.525210 & 9.745609 & 11.180719 \\
$\mathrm{C}$ & 10.201989 & 10.718264 & 12.666700 \\
$\mathrm{C}$ & 10.423850 & 10.929599 & 9.103190 \\
$\mathrm{C}$ & 12.275453 & 10.593281 & 10.701885 \\
$\mathrm{C}$ & 8.339578 & 13.558344 & 11.104549 \\
$\mathrm{O}$ & 7.860480 & 8.710480 & 11.082283 \\
$\mathrm{H}$ & 10.787764 & 12.747371 & 11.758351 \\
$\mathrm{H}$ & 10.388524 & 8.705973 & 11.542899 \\
$\mathrm{H}$ & 11.167884 & 10.583814 & 13.154990 \\
& & & \\
\hline
\end{tabular}




$\begin{array}{cccc}\text { H } & 9.407516 & 10.763136 & 13.417744 \\ \text { H } & 10.878409 & 11.859576 & 8.734113 \\ \text { H } & 10.859963 & 10.106415 & 8.526815 \\ \text { H } & 9.350778 & 10.978777 & 8.898839 \\ \text { H } & 12.783933 & 11.439711 & 10.221777 \\ \text { H } & 12.626760 & 10.530428 & 11.736323 \\ \text { H } & 12.563303 & 9.672761 & 10.180292 \\ \text { H } & 6.877163 & 11.184902 & 10.818423 \\ \text { H } & 7.271334 & 13.648732 & 10.886169 \\ \text { H } & 8.913685 & 14.025911 & 10.291242 \\ \text { H } & 8.575809 & 14.116705 & 12.020500\end{array}$

